\title{
I. Dünya Savaşı'nda Müttefiklerin (İngiltere-Fransa) İskenderun Çıkarması Planı ve İkinci Çanakkale Korkusu
}

\author{
Landing Operation Plain of Allies (Britain and France) on \\ Alexandretta in WWI and Fear of the Second Gallipoli
}

\author{
Ü. Gülsüm Polat*
}

Özet:

Osmanlı Devleti'nin savaşa girmesinden kısa süre sonra başlatılan Çanakkale Harekâtı başta Ingiltere olmak üzere müttefiklerin büyük umutlar bağladığı ve neticesinin kolay ve hızlı biçimde alınacağına inandıkları bir operasyondu. Ingiliz savaş kadrosunun en tepe noktasındaki isim olarak Savaş Bakanı Lord Kitchener başta olmak üzere diğer bazı yöneticiler eş zamanlı olarak Iskenderun'a da bir çıkarma operasyonu başlatılması konusunda girişimde bulunmuşlar ve bu konuda Fransız müttefikleriyle fikir birliğine ulaşmaya çalışmışlardı. Oysaki daha Çanakkale operasyonunun ilk günlerinden itibaren beklenenin aksine kolay ve hızl bir deniz zaferi elde edilemeyeceği anlaşılmıştı. Ayrıca Ingiltere ve Fransa arasındaki müttefik olmalarına rağmen yaşanan güç mücadelesi, fikir ayrllıkları ve bilhassa Suriye'nin savaş sonrası statüsü noktasında mutabakatın tam olmaması nedeniyle İkenderun üzerine bir operasyon planı hayata geçirilemedi. Bu noktada Ingiliz makamlan bölgedeki Ermeni nüfusunun desteğini alacaklarını ve burada bulunan az sayıda Osmanlı birliğinin harekâtın başarısını kolaylaştıracağını hesaplamalarına rağmen böylesi bir operasyona kalkışamadılar. Çanakkale'de sergilenen direniş önce Fransız müttefiklerini ve Ingiliz savaş ekibini her türlü hazırlı̆̆a răgmen ikinci bir operasyon fikrinden kesin olarak vazgeçirdi.

Anahtar Kelimeler: İkenderun, Lord Kitchener, W. Churchill, çıarma

\begin{abstract}
Gallipoli Campaign, launched shortly after the Ottoman Empire's entry into the WWI, was an operation from which the allies, especially Britain, expected a fast and easy result. Lord Kitchener, British Secretary of State for War and the most important person in British war council, made joint attemps with the other officials to launch a landing operation in Alexandretta and for this purpose, they sought consensus with the French allies. Yet, even from the early days of the Dardanelles Campaign, it became clear that a victory would not be won easily and quickly contrary to expectations. Besides, despite being allies, the power struggle and controversies between Britain and France, especially the lack of consensus over Syria's post-war status, prevented an operation on Alexandretta. Although at this point the British authorities expected that the Armenian population in the region would support them and the scarcity of Ottoman troops in the region would ease the success of the operation, they did not dare such an operation. Despite all preparations, the resistance in Gallipoli deterred the French allies and the British war council from launching a second operation.
\end{abstract}

Key Words: Alexandretta, Lord Kitchener, W. Churchill, landing.

* Yrd.Doç.Dr., Dumlupınar Üniversitesi, Fen-Edebiyat Fakültesi, Tarih Bölümü, Kütahya, e-mail: gulsumpolat26@gmail.com

Akademik Bakış 21 Cilt 7 Sayı 14 Yaz 2014 


\section{Giriş}

İngiltere için mevcut geniş sınırları ile Osmanlı Devleti'nin varlığını devam ettirmesi 1914'e gelindiğinde gerekli ve mümkün görünmüyordu. Oysaki savaştan kısa zaman evvel Osmanlı Devleti'nin hayat sahasını İngiltere'nin muhtemel rakiplerine karşı elinde tutma çabası, İngiliz siyasetçiler tarafından sempatiyle karşılanıyordu. Trablusgarp Savaşı'nda İtalyanlara karşı savaşan Türklere karşı Winston Churchill'in sempatisini bu bağlamda değerlendirmek mümkündür' Aslında dönemin klasik bakış açısı "Avrupa'nın hasta adamı"nın kaçınılmaz olan yıkımıyla İngiltere'nin direk bölgesel çıkar elde edebilmesi beklentisinin karşılanmaması ile bu sempati 1914 başlarında tamamen sona ermişti. Artık savaşta yerini alan Osmanlı Devleti'nin karşısında özellikle donanmasıyla savaşın en önemli deniz gücü olan İngiltere, paylaşılmasına kesin gözüyle baktığı topraklardan en stratejik noktaların ele geçirilmesinin yollarını arayacaktı.

Diğer rakiplerin de tarihten gelen fakat özellikle de ekonomik nedenlere dayalı olarak Osmanlı Devleti'nden oldukça fazla beklentileri vardı. Kuzey komşusu Rusya Osmanlı Devleti'nden özellikle 19. yüzyılda önemli kazanımlar elde ettiği gibi bağımsızlık hareketlerinde de Balkanlarda kilit rol oynamış ve uzun zamandır arzu ettiği Boğazlar ve İstanbul'un kendi yönetimine geçmesini İngiltere ve Fransa ile yaptığı İttifak Antlaşması ile girdiği grubun muhtemel bir savaşta Almanya'yı ezmesine bağlamıştı. Fransa için de, Osmanlı'nın mevcut haliyle varlığı hiçbir anlam ifade etmiyordu. Fas, Cezayir, Tunus'taki çıkarlarının Suriye'ye de intikali müttefiki İngiltere ile yaptığı işbirliğinden beklentileriydi. Bunun için İngiliz donanması ile işbirliği yapacak ve Boğaz'ı birlikte zorlayacaklardı.

Ayrıca Balkan Harplerinde Edirne'yi son anda geri alan Osmanlı Devleti için yeni kurulan Bulgaristan ve Yunanistan gibi devletlerden de bir saldırı gelmesi hiç de uzak bir ihtimal değildi. Savaşın başlarında Sofya'da askeri ataşe olarak bulunan Mustafa Kemal Paşa savaşın başlarında buradaki belirsiz havayı merkeze bildirmekteydi ${ }^{2}$.

Akademik

Osmanlı Devleti'ni yönetenler de yaklaşan savaşta bu devletlerle muhtemel savaş alanlarını tahmin ediyorlardı. Daha sonra anılarını yazan dönemin yönetici kadrolarının hemen hepsi tarafsız kalmanın imkânsızlığını ve paylaşılacak topraklar olarak görülen Osmanlı'nın Almanya yanında savaşa girmekten başka çaresinin olmadığını yazmaktadır. Bu bağlamda II. Abdülhamid döneminde ilki gelen Alman Askeri Islah Heyeti ile özellikle askeri sahadaki Alman etkisinin, Bağdat ve Hicaz demiryolu imtiyazlarının Almanlara verilmesi ile ekonomik sahada da dikkat çekici bir noktaya gelmesi savaşa birlikte girilecek müttefikin sürpriz olmadığını göstermektedir. Savaş arifesinde bu Türk-Alman yakınlaşması geniş menfaatleri nedeniyle İngiltere tarafından kaygıyla izleniyordu.

1 Martin Gilbert, Winston S. Churchill, (1914-1916) Vol:3, Part I, Heinemann, London 1972, S.188-189.

2 Sofya Askeri Ataşesi, Mustafa Kemal in Raporları (Kasım 1913- Kasım 1914), Yay. Haz: Ahmet Tetik, Genelkurmay Askeri Tarih ve Stratejik Etüt Dairesi Başkanlığı Yay., Ankara 2007. 
Almanlar Türklerle imzalanan ittifak anlaşmasına bir an evvel işlerlik kazandırmak istiyorlardı․ Tam da bu günlerde İngiliz donanmasının takibinden kaçan iki Alman savaş gemisinin Boğazlara girmesi her iki taraf için de geri sayımı başlattı. Artık İstanbul'un atacağı her adım stratejik öneme sahipti. Bir taraftan gizli antlaşmanın getirdiği yükümlülükler diğer yandan tarafsızlık görüntüsünde yürütülen seferberliğin devam etmesi nedeniyle savaşta olunmaması ve itilaf güçlerine fiili bir saldırı yapılmaması 29 Ekim 1914'e kadar geçen sürede Çanakkale Boğazı önünde İngiliz filosunu tetikte bir bekleyişe zorladı. Akdeniz Donanmasının bir kısmını oluşturan bu filonun kumandanı Tuğamiral Ernest Troubridge'e Deniz Kuvvetleri Bakanı Churchill'in gönderdiği yazıda kendisinin yegâne görevinin Gooben ve Breslau'ın hangi bayrakla olursa olsun Çanakkale Boğazı'ndan çıkması durumunda batırması olduğu bildirilmişti. Churchill Amiral Troubridge'ye yazdığı bu yazıda "Dïşman ne pahasına olursa olsun gece yahut gündüz yok edilmeli" diyordu . Bu sert tavır Osmanlı Devleti'nin henüz kararının netleşmediği bir dönemde İngiltere'nin İstanbul elçisi L. Mallet'e göre yanlıştı. Dışişleri Bakanlığı'na gönderdiği yazıda İngiliz savaş gemisine verilen bu emrin doğruluğuna “inanamadı̆̆ını” ve böyle bir davranışın İngiltere'yi haksız çıkaracağı gibi bunun Almanlar tarafından da kullanılacağını belirtiyordu. Ayrıca İstanbul'daki Fransız elçisinin de bu konuda hemfikir olduğunu açılıyordu5 ${ }^{5}$ İngiliz Hariciyesi Churchill'in bu sert talimatına rağmen ilk hareketin Türklerden beklenmesini İngiliz filosuna bildirmişti ${ }^{6}$. Hatta Churchill aynı emri Malta'daki İngiliz Koramiral Sackville Carden'a da vermeyi de ihmal etmiyordu. Churchill Koramirale hangi bayrak ile olursa olsun Çanakkale Boğazı'ndan çıkan bu gemilerin batırılmasını emrediyordu ${ }^{7}$.

Diğer yandan İngiliz Deniz Kuvvetleri Bakanı Osmanlı Devleti'nin savaşa dair kararını beklemeden Osmanlı Bahriyesi'ni ıslah amacıyla 1912 yılından beri İstanbul'da bulunan İngiliz donanma heyetini geri çağırmayı uygun gördü. Amiral Limpus'a elçi Mallet aracılığıyla gönderdiği yazısında Churchill, Türk donanmasını belli bir seviyeye getirdiklerini ve mevcut şartlar altında yani Türk donanmasının Almanlar tarafından "felç edildiği" bir ortamda buradaki görevlerinin sona erdiğini bildiriyordu ${ }^{8}$.

Bu hazırlıklar yanında Deniz Kuvvetlerinden, İngiltere'nin Akdeniz filosundan Indefatigable gemisine gönderilen yazıda hiçbir şekilde Türk gemilerinin kömür elde etmesine izin verilmemesi istendi. Zira bu kömürün Alman savaş

Akademik Bakış 23 Cilt 7 Sayı 14 Yaz 2014

3 Vahdet Keleşyılmaz, "Belgelerle Türkiye'nin Birinci Dünya Savaşına Giriş Süreci”, Erdem, C: 11, S: 31, May1s 1999, s. 139-153.

4 Churchill Archives, Churchill College, Cambridge, İngiltere (bundan sonra CHAR), 13/35-4, 8 Eylül 1914.

5 The National Archives, Kew, Londra, İngiltere (bundan sonra TNA), Foreign Office (Bundan sonra FO) 371/2138, 40532/556, 17 Ağustos 1914, Mallet'den Edward Grey'e.

6 TNA, FO, 371/2138, 40611/395, 18 Ağustos 1914, Edward Grey'den Mallet'e.

7 CHAR, 13/37-78, 21 Eylül 1914.

8 CHAR, 13/35-5, 9 Eylül 1914 
gemilerinde kullanıldığı belirtiliyordu9 . Türk Hükümeti ani bir kararla Boğazları tüm ulaşıma kapatmıştı. Churchill'in ${ }^{10}$ İstanbul elçisi gibi yani Türklerden bir hareket gelmedikçe karşı bir harekete girişilmemesi niyetinden uzak olduğu anlaşılıyordu. Ancak Boğazlardan çıkması durumunda batırılmak istenen bu gemiler Osmanlı Devleti tarafından Karadeniz'e çıkarılmasının ardından Odessa, Sivastopol, Teodosya gibi limanları "Rusların saldırısına karşılık" olarak bombalamasıyla İngiliz filosunun tetikte bekleyişi sona ererek hareket halini alacaktı. Bahriye Nazırı Cemal Paşa anılarında bu vakanın gerçekleşmesinin hemen akabinde Enver Paşa tarafından kendisine bilgi verildiğini ve bunun savaşa resmen girmiş oldukları anlamına geldiğini kabul ettiğini yazmaktadır ${ }^{11}$. Bu olay Rusya nezdindeki İngiliz elçisi tarafından da hemen Dışişleri Bakanlığına bildirilmişti. St. Petersburg'daki İngiliz Elçisi Buchanan, Rus Dışişleri Bakanı ile yaptığı görüşmede Rusya'nın savunmada kalacağını bildirdiğini belirtiyordu' ${ }^{12}$. Osmanlı Devleti'nin bu davranışı ile resmen savaşa girdiği kabul edildiğinden mesele derhal Fransa'ya da haber verilmişti ${ }^{13}$.

Bunun üzerine diplomatik ilişkiler kopmuş ve bu devletlerin elçileri İstanbul'dan ayrılmıştı. Artık Çanakkale Boğazı'nda bekleyen İngiliz filosu için beklemenin anlamı olmayacaktı. İngiliz filosunun görevi bundan böyle tarafsız ülke sularında bekleyen Alman gemilerini bulmaktan farklı olarak Çanakkale Boğazı'na bir deneme saldırısı yapılmasına dönecekti. Zaten bir süredir Çanakkale istihkâmlarını sağlamlaştıran Osmanlı askeri erkânı da olası harbe iştirak ile İngiliz filosunun Çanakkale boğazını zorlayacağını biliyordu. Kasım ayının ilk günü İngiliz Deniz Kuvvetleri Komutanlığı'ndan verilen bir emirle Çanakkale Boğazı'na bir nevi deneme saldırısı yapılması istendi. İngiliz Indefatigable gemisine verilen emirde Fransız gemileri ile birlikte, risk alınmaksızın, en uygun şekilde ve Çanakkale Boğazı'na 14.000 ila 12.000 yarda $^{14}$ yanaşmak suretiyle bombardıman yapılması isteniyordu ${ }^{15}$. Alınan emir üzerine İngiliz ve Fransız gemilerinden mürekkep bir filo (Indefatigable, Indomitable, Suffren, Verite gemileri) Çanakkale Boğazı'na 1.300 yardadan yaptıkları atışlarla bombardıman

Akademik

ettiler. Bombardımanın neticesi ile ilgili merkeze bilgi veren Amiral Limpus siyah dumanların yükseldiğini ve Türk tabyalardan cevap verildiğini ve batan gemi olmadığı bildiriyordu' ${ }^{16}$. Bu çarpışma başlayacak olan büyük Çanakkale harbinin habercisiydi. Kasım ayının devamı süresince Türklerin boğazlardaki gücü kestirilmeye çalışılıyor ve temkinli olunduğu anlaşılıyordu.

9 TNA, FO, 371/2143, 55006, 1 Ekim 1914, Deniz Kuvvetleri Bakanlığından Indefatigable'a.

10 Çalışmanın geri kalanında yalnızca Churchill olarak ifade edilecektir.

11 Cemal Paşa, Hatıralar, Haz: Alpay Kabacalı, İş Bankası Yay., İstanbul 2006, s. 158-160.

12 TNA, FO, 371/2145, 64915/571, 29 Ekim 1914, Buchanan'dan Edward Grey'e.

13 TNA, FO, 371/2145, 64915/831, 29 Ekim 1914, Edward Grey'den F. Bertie'ye.

14 Bir yarda 0,9144 m'ye eş değerdir. Bu hesapla 14000 yarda 12801,6 metre, 12000 yarda ise 10972,8 metredir.

15 CHAR, 13/37-96, 1 Kasım 1914

16 CHAR, 13/37-97, 3 Kasım 1914 
Çanakkale saldırısının her türlü ayrıntının göz önüne alınarak ve Fransız donanmasıyla yapılacak işbirliğinin tamamlanmasından sonra başlatılması düşünülüyordu. Ancak bir taraftan da hesaplar ve planlar yapılmaktaydı. Buna göre Çanakkale Boğazına yapılacak saldırı İngiliz yetkililerin yaptığı hesaba göre üç ya da dört hafta sürecekti. Plana göre saldırıya katılacak savaş gemileri, zırhlıları, mayın arama gemileri, uçak kaldırabilen gemiler uzun namlulu silahlarla güçlendirilmiş olacaktı. Ayrıca zayiatlar da göz önüne alınarak yedek olması gereken gemiler de hesaba katılıyordu. Bunlar boğazı koruyan tabyaları kademeli olarak bombardıman ile azaltacaklardı. Bu amaçla bahsi geçen deniz gücünün 7-15 Ocak 1915 tarihleri arasında bir araya gelmesi gerekiyordu. Fransızlarla İngiliz donanması bu planı ortak tatbik etmeyi uygun bulmuşlardı. Zira buna dair Churchill'in hazırladığı planda Fransızlara düşen görevler sıralanıyordu $^{17}$. Çanakkale'de büyük bir deniz operasyonu olacağının kesin olduğu bu günlerde İngiliz makamları Akdeniz filosuna bir başka Türk limanına bir operasyon emri verilip verilmemesi fikrini tartışıyorlardı.

\section{İskenderun Limanına Eş zamanlı Operasyon Fikri}

İskenderun'un hayati öneme sahip bir nokta olması onun hem bir liman şehri hem de Osmanlı Devleti'nin Irak ve Suriye topraklarına geçişi sağlayan demiryolu için kilit bir noktada olmasından ileri gelmekteydi. İskenderun, savaş arifesinde sadece İngiltere ve Fransa açısından değil; Almanya için de stratejik bir yer olarak görülüyordu. 15 Şubat 1914'de Berlin'de gerçekleştirilen AlmanFransız antlaşması bağlamında İskenderun'un doğrudan doğruya Halep'e ve Halep'i Meskene yolu ile Irak'ta bir noktaya Bağdat demiryolu ile bağlama düşüncesinde olduğunu Almanya açıklamıştı ${ }^{18}$. Uluslararası ticaretin gelişmesi, sadece yabancılara değil doğal yollar üzerinde bulunan İskenderun limanının önemini Türklere de göstermişti. Ayrıca 19. yüzyıldan itibaren İskenderun'da o tarihe kadar çok az olan ecnebi tüccarların yerleşiminin de görülmesi tesadüf değildi ${ }^{19}$. İskenderun, Osmanlı topraklarında petrolün ilk bulunduğu yer olmaSı açısından da 20. yüzyılda önemi daha da anlaşılacak bu doğal zenginliğe de sahipti. 1889'da İskenderun'un Kabaev nahiyesindeki Çingen köyünde keşfedilen petrol, önce petrolü keşfeden askeri müteahhit Ahmet Necati Bey ardından başka müteahhitler tarafından işletilmiş ve I. Dünya Savaşı sırasında işletme imtiyazı feshedilmişti ${ }^{20}$.

İşte bu stratejik önemine binaen daha savaşın ilk günlerinden itibaren İskenderun Limanı İngiliz ve Fransız zırhlılarının gözetimi altındaydı ${ }^{21}$. Akdeniz

17 CHAR, 2/74-51, 16 Ocak 1915.

18 Vahit Çabuk, "Birinci Dünya Savaşı Öncesinde İskenderun'un Stratejik Durumu”, I. Hatay Tarih ve Folklor Sempozyumu, Antakya 1991, s.11.

19 A.Faik Türkmen, Mufassal Hatay, 3. Cilt, Reklam Basımevi, İstanbul 1937, s. 559

20 İdris Bostan, "Osmanlı Topraklarında Petrolün Bulunuşu ve İskenderun'da İlk Petrol İşletme Çalışmaları", Coğrafya Araştırmaları, C. 1, S.2, Ankara 1990, s. 129-135.

21 Başbakanlık Osmanlı Arşivi/ İstanbul (Bundan sonra BOA), DH.ŞFR, 457/73, Halep valisi Celal Bey'in İngiliz ve Fransız kruvazörlerinin İskenderun civarındaki faaliyetleri hakkında telgrafı.

Akademik Bakış 25 Cilt 7 Sayı 14 Yaz 2014 
donanmasının önemli kruvazörlerinden Doris în İskenderun civarında bulunduğu hatta sahillere atış yaptığı rapor ediliyordu ${ }^{22}$.

Osmanlı Devleti'nin Suriye ve Arap Yarımadası ile bağlantı noktası olan İskenderun ve civarına Çanakkale Boğazı'na paralel olarak bir operasyon düzenlenmesi İngiliz makamları arasında müzakere ediliyordu. Hatta Fransız yetkililere verilmek üzere hazırlanan ve "ağız sıkıllğının hayati önem taşıdığı" belirtilen taslak planda İskenderun'un ele geçirilmesi sayesinde Türk demiryolu ulaşımının kesileceği yani oldukça önemli bir noktanın zabt edilmiş olacağı belirtiliyordu. Bu operasyon gerçekleştirilirse karaya çıkacak İngiliz kuvvetlerinin güvenliğinin İngiliz gemileri tarafından sağlanması gerekliliğinin ortaya çıkacağı ve bunun da halihazırda Mısır sularında olan bazı gemiler tarafından yapılabileceği belirtiliyordu. Bu bağlamda yine Fransız donanmasına düşen görev, Latakia'dan Mısır sınırına kadar olan tüm Suriye sahillerinin gözlemlenmesi idi. Eğer gerekirse bunun için İngiliz ve Fransız amiralleri arasında yetki paylaşımı yapılabileceği de belirtiliyordu²3.

Çanakkale Boğazı'nın ele geçirilmesi nasıl ki İstanbul'un düşmesi anlamına gelecekse, İskenderun'un daha savaşın başında İngilizlerin eline geçmesi bu bölgeden hareketle güneye sevk edilen tüm askeri seferberliği durduracaktı. Bu durumun farkında olan Deniz Kuvvetleri Bakanı Churchill, Çanakkale Boğazı'na yapılacak saldırıdaki ısrarına benzer şekilde İskenderun'a da bir çıkarma yapılmasını arzu etmekteydi. Bu amaçla 20 Ocak 1915'de Amirallik Birinci Lordu (First Sea Lord) Fisher'a gönderdiği "çok gizli" mektubunda Queen Elizabeth gemisinin buraya ulaşır ulaşmaz Çanakkale Boğazı saldırısının başlatılmasını ve 15 Şubat 1915'de ateş açılmasını öneriyordu. Churchill'e göre, Çanakkale Boğazına yapılacak saldırıda Indefatigable, Queen Elizabeth, ve diğer 3-4 İngiliz savaş gemisinin mayın tarama gemileri ile birlikte bir de Ark Royal isimli geminin ilk saldırı için yeterli olacağını, geriye kalan Fransız gemilerinin Malta, İskenderiye ve İskenderun arasında paylaştırılması gerektiğini vurguluyordu. Hatta Churchill şöyle diyordu; "Çanakkale Boğazına saldırı başlar başlamaz, İkenderun ele

Akademik geçirilmeli. Bu nedenle, eğer biz Çanakkale Boğazında ilerleme kaydedemezsek bundan maksadımızın İskenderun'un ele geçirilmesinin üzerini örttügüümüz numarasını yapabiliriz. Bu bakış açısı Şarkî bakış açısında önemlidir. "24. Churchill'in mektubunun devamından İskenderun'a yapılması planlanan saldırı hazırlıkları ile ilgili H.B. Jackson'un çalıştığı anlaşılıyordu ${ }^{25}$. Ancak onun özellikle dikkat çektiği nokta Çanakkale'ye

$22 B O A$, DH.ŞFR., 459/78, 17 Kanun-ı sani 1330; Doris zırhlısının 1915 yılı operasyonları ve bu bağlamda İskenderun civarındaki faaliyetleri için bkz: Edward J. Erickson, "Captain Larkin and the Turks: The Strategic Impact of the Operations of HMS Doris in Early 1915", Middle Eastern Studies, Vol. 46, No. 1, Ocak 2010, S. 151-162.

23

24

25 
yapılacak saldırı ile İskenderun'a yapılacak saldırının mutlaka eş zamanlı başlatılmasıydı. Bu görüşünü Kitchener' ${ }^{26}$ tekrarlıyordu $^{27}$.

İskenderun'a yapılması planlanan bu saldırının hazırlıkları ve görüş alışverişleri devam ettiği günlerde İngiliz filosuna mensup bazı gemiler İskenderun Limanını çok sıkı bir gözetim altında tutuyorlardı. Öyle ki, Doris isimli İngiliz zırhlısı İskenderun'da Türk bölüklerinin ve savaş materyallerinin nakledildiğini gözlemlemişti. Bunun üzerine bir ültimatom gönderen zırhlı, "hayatta kalmak isteyenlerin" cephane ve demiryolu malzemelerini 24 saat içerisinde terk ederek bölgeden uzaklaşmalarını; eğer bunu yapmazlarsa hükümet binalarının, liman işletmelerinin, iskelenin ve demiryolu işletmelerinin bombalanacağını bildirmişti. Bunun üzerine savaş malzemeleri limandan iç kısımlara taşınmış ve ültimatoma karşılık eğer herhangi bir bombardıman olursa ve bu bombardımanda Osmanlı tebaası zarar görürse İngiliz rehinelerin öldürüleceği eğer herhangi bir Osmanlı binası zarar görürse İngiliz mal ve mülküne aynı karşılığın verileceği cevabı verilmişti. Bu cevap üzerine İngiliz zırhlısı yeniden düşünmeleri için 24 saat verdikten sonra, Payas'ın kuzeyine giderek burada bir demiryolu köprüsünü bombalamıştı. 22 Aralık'ta geri dönen zırhlıya İskenderun'dan verilen cevapta burada savaş malzemesi olmadığı ve eğer gerekli mühimmat verilirse iki demiryolu lokomotifinin yok edilebileceği bildirilmişti. Bu konuda yapılan uzlaşma ile patlatma işlemi yapılmış ve Doris isimli zırhlı limanı bombalamamış$\mathrm{t}^{28}$. Doris'in bu bölgede bulunması, gerekli tedbirleri alması ve İskenderun'dan sevk edilen özellikle ağır silahları ele geçirmesi isteniyordu ${ }^{29}$. Bu günlerde İskenderun ile Payas arasındaki sahile yaklaşarak sahili tehdit eden bazı İngiliz gemilerinin ${ }^{30}$ varlığından söz ediliyordu. Bu bağlamda görev türü hakkında bilgi verilmemekle beraber "Musa Kazım Bey" fırkasının İskenderun üzerinden döneceğinden söz edilerek İskenderun'da dikkatli olması gerektiğine dikkat çekiliyordu ${ }^{31}$. Zaten Aralık ayı içerisinde bazı Fransız kruvazörleri İskenderun ile Payas arasındaki demiryolunu bombardıman etmişlerdi. Diğer yandan Halep vilayetinden gelen haberlerde de İngiliz ve Fransız gemilerinin İskenderun Limanı çevresindeki askeri hareketlilikleri dikkat çekiciydi ${ }^{32}$.

26 Savaş Bakanı Kitchener'ın "Lord" ve ardından da "Earl" gibi unvanları çalışmada tekrar olmaması açısından yazılmayacaktır.

27 CHAR, 2/74- 52, 20 Ocak 1915.

28 TNA, FO, 371/2478, 352/935, 3 Ocak 1915; Cheetham'dan Edward Grey'e; Telgrafın aynısı Churchill Arşiv'de de göze çarpmaktadır; CHAR, 13/67, 3 Ocak 1915, 4-5.

29 CHAR, 13/67,10, 9 Ocak 1915

30 Bu konuda Halep vilayetinden gelen bir başka yazıda Doris zırhlısının İskenderun Payas arasını sık sık tarassut ettiği ve bazı noktaları topa tuttuğu Vali Celal Bey tarafından bildirilmekte ve Kazım Bey müfrezesinin dikkatli olması söylenmekteydi. BOA, DH.ŞFR., 456/108, 24 Kanun-1 evvel 1330, Doris zırhlısı ertesi gün saat dokuzda da Payas ile Sarıseki arasını ve saat ondan itibaren de Sarıseki civarını bombardıman etmiş ayrıca karaya asker çıkardı ̆̆ı bildirilmişti. $B O A$, DH.ŞFR., 456/1 16, 25 Kanun-1 evvel 1330. Ancak kıyıya asker çıkarma hadiseleri son bulmadı Halep vilayetinden sık sık bu konuda yazı gelmekteydi. Hatta jandarmayla çatışmaya girilmesi durumu dahi olmuştu. BOA, DH.ŞFR., 460/15, 19 Kanun-1 sani 1330.

$31 B O A$, DH.EUM.4.Şb., 1/19, 6 Ocak 1915

$32 B O A$, DH.EUM. 6.Şb., 2/67, 28 Ocak 1915.

Akademik Bakış 27 Cilt 7 Sayl 14 Yaz 2014 
İngiliz Deniz Kuvvetleri Bakanı Churchill, Fransız Deniz Kuvvetleri Komutanı Victor Augagneur ile kuvvet dağılımı hakkında tam bir mutabakata varmaya çalışıyordu. Özellikle bir Fransız Koramiralinin İskenderun'u da içine alan ve Levant olarak tabir edilen Bilad-1 Şam bölgesine görevlendirilmesinin uygun olacağını düşünüyor fakat diğer taraftan İskenderun'a yönelik bir deniz operasyonunda Franzsızların yer almak istemediğini Dışişleri Bakanı Edward Grey'e bildiriyordu. Ayrıca şimdilik Savaş Bakanı Kitchener'ın, İskenderun üzerine yapılacak seferle ilgili bir tarih tespit etmediğini belirtiyordu. Bunun için kesin bir şeyden söz etmenin gereksiz olduğunu da ekliyordu. Dışişleri Bakanı Edward Grey'den Fransız Deniz Kuvvetleri Bakanı (French Minister For Marine) Augagneur ile görüşmesi esnasında onunla mesele hakkında konuşmasını istiyordu. Ancak Edward Grey, Fransızların özellikle İskenderun çıkarmasındaki fikirlerinin öğrenilmesinin önemli olduğunu ve Fransızların Suriye'de şüphelerini uyandırırlarsa Akdeniz'de ve belki her yerde samimi işbirliğinin ölümcül darbeler alabileceğini hatırlatıyordu. Ayrıca Fransız Deniz Kuvvetleri Bakanı ile yemekte bir araya geleceğini yazıyordu33. Bu kaygıların aksine 31 Ocak 1915'te Augagneur Çanakkale Boğazı'na ve İskenderun'a yapılacak deniz saldırılarında İngiltere ile işbirliğini kabul ettiklerini bildiriyordu ${ }^{34}$. Bu işbirliğinin İngiltere için ve özellikle Churchill için oldukça memnuniyet verici olduğu açıktı. Zira 20 Şubat tarihli bir değerlendirme konuşmasında Churchill, Rusya'nın durumu ve Batı'daki İngiliz- Fransız hattını değerlendirdikten sonra şunları söylüyordu: "bizim için kesin olan nokta... Balkan Yarımadasıdır. Askeri ve denizdeki tam bir işbirliği ve mevcut kuvvetlerle Mart sonuna kadar İstanbul'u /Constantinople) almak için kesin şeyler yapabiliriz ve Avrupa'daki (bundan Edirne hariçtir) tüm Türk kuvvetlerinin ele geçirilmesi ya da yok edebilmesi mümkündür. Bu şok Sirbistan in kaderi belirlenmeden önce hayati olabilir. O'nun [İstanbul'un alınmasl] etkisi tüm Balkanlarda belirleyici olacaktır. Türkiye'yi /Osmanli Devleti/ askeri bir faktör olarak ortadan kaldırilacaktır ${ }^{35}$. Churchill İstanbul'u 36.000 kişiden oluşan iki tümen (29. Tümen ve diğer bir gönüllü tümeni), 12.000 kişilik Limnos tümeni, 39.000 kişilik Mısır'dan getirilecek iki Avustralya tümeni, 20.000 kişilik bir Fransız ile 8.000 kişilik bir Rus tugayından oluşan toplam 115.000 kişilik bir kuvvetle ele geçirmeyi hesaplıyordu ${ }^{36}$. Bu tavrı

Akademik ile Churchill Osmanlı Devleti'ni savaşın sonuna kadar bölgede ayakta kalamayacak kadar zayıf görmekle birlikte yine de Osmanlı Devleti'nin bu haliyle dahi varlığının belirleyici bir rol oynadığını kabul etmekteydi. Ancak İstanbul'un ele geçirilmesi yahut Gelibolu ele geçirilirken bir kuvvetin ellerinin altında olmasının önemli olduğunu zira bu esnada bir ihtilal çıkması halinde bu kuvvetten

33 CHAR, 2/74-54, 26 Ocak 1915.

34 CHAR, 2/74-56, 26 Ocak 1915.

35 CHAR, 2/74-57, 25 Şubat 1915; Churchill bu değerlendirmeyi Başbakan'a, Chancellor of the Excequer [Kabine Reisi] (David Lloyd George olmalı) ve Mr Balfour'a yapmıştı. Ayrıca 20 Şubatta Savaş Konseyinde özet olarak kendisi tarafından kullanılmıştı. 
faydalanılabileceğini Kitchener'a yazmaktaydı ${ }^{37}$. Öyle anlaşılıyor ki, Churchill İstanbul'un ele geçirilmesi konusunda 39.000 kişilik kuvveti çok da yeterli görmemekteydi. Yahut halk isyanının patlak vermesi durumunda yetersizliğinden şüphe etmekteydi. Tüm risklere rağmen Çanakkale Boğazına yönelik hazırlıklar hızla devam ettirildi. Ancak aynı kararlılık, İskenderun'a yapılacak çıkartma için geçerli değildi.

\section{İskenderun'a Yapılması Planlanan Harekatın Gerekçeleri}

Aslında Churchill'in bu konudaki en büyük destekçisi Savaş Bakanı Kitchener idi. Kitchener tarafından yazılan 16 Mart 1915 tarihli bir memorandum (nota) Ulusal Savunma Komitesine (Committee of Imperial Defence)'a sunulmuştu. Bu notada İskenderun ve Mezopotamya'ya dair önemli öngörülere yer veriliyordu. Buna göre Kitchener, savaşın getirisi olarak Rusya'nın Boğazlara hakim olmasının ve Fransa'nın da yıllardır hevesle istediği Suriye'deki hakimiyetini sağlamlaştırmasının İngiltere'nin Mısır'daki varlığını önemli şekilde etkileyebileceğini yazıyordu. Ayrıca barışın imzalanmasından sonra eski kin ve kıskançlıkların canlanabileceğini hatırlatıyordu. Yani yakın gelecekte Rusya ya da Fransa ile yahut her ikisiyle birden bir husumet içerisinde bulunma ihtimalini akılda tutarak Osmanlı Devleti'nin Asya topraklarının paylaşılması zamanı geldiğinde, İngiltere'nin çıkarlarının korunabilmesi için bu noktaların hatırlanması gerektiğini belirtiyordu. Kitchener'a göre Rusya'nın bir Akdeniz devleti olmasıyla Boğazların güvenli sığınak şeklindeki konumundan dolayı uzak noktalara donanma sevkedecek bir güce sahip olacaktı. Ayrıca Fransa, Suriye'de Nil Deltası'na yakınlık gösterecek ve bu durum Mısır'ın stratejik konumunu önemli ölçüde etkileyebilecekti. Hatta bu şartlar altında bu devletlerden biriyle yahut her ikisiyle İngiltere karşı karşıya gelirse, İngiltere'nin Hindistan ile Süveyş Kanalı aracılığıyla iletişimi ciddi anlamda tehlikeye atılmış olacaktı ve böylesi bir durumda ihtiyaç duyacağı savaş gemisi limanına Mısır'ın sahip olmaması büyük bir dezavantajdı. Kitchener tüm bu ihtimalleri göz önüne alarak İskenderun'un ele geçirilmesinin ne denli önemli olduğunu vurgulamaktaydı. Savaş Bakanına göre İskenderun'un ele geçirilmesi tamamıla Mezopotamya'nın geleceğiyle alakalıydı. Yani bu savaş sonucunda Fırat Vadisi'nin ele geçirilmesiyle ilgili bir niyet yoksa İskenderun'un, İngilizlerin elinde olması tehlikeli bir ileri karakol kurulmasından başka bir anlam ifade etmeyecekti. Ancak bu İngiltere için sorumlulukları kadar getirisi olan bir ileri karakol değildi. Diğer yandan eğer Mezopotamya'nın elde edilmesi tasarlanıyorsa İskenderun'un ilkin bir İngiliz kuvvetiyle elde edilmesi gereklilikti. Bu gerekliliği dile getiren Kitchenar memorandumunda İskenderun'un neden ele geçirilmesi gerektiği konusunda ayrıntılar vermekteydi. Hazırladığı planda Boğazlara Rusya'nın ve Suriye'ye de Fransızların hakim olması ile ortaya çıkacak bir meselenin savaşa varması durumunda, Mezopotamya'nın tıpkı Mısır 
gibi askeri açıdan desteklenmesinin kaçınılmaz olduğunu vurgulamaktaydı. Yani İngiltere'den Mezopotamya'ya Süveyş Kanalı, Kızıldeniz ve İran Körfezi vasıtasıyla birlik getirilmesinin iki haftadan fazla süreceği ve oradan da trenle hareket edeceği hesaplanmalıydı. Kitchener hâlihazırdaki müttefiki olan fakat yakın gelecekte muhtemel düşmanları olarak gördüğü Rusya ve Fransa'dan bu geleceğe dair planlarında "düşman-(enemy)" şeklinde söz etmekteydi. Ona göre, düşmanların özellikle de Rusya'nın, Ermenistan üzerinden dağlık alandan ilerlemesi veya güneydoğudan yapacakları bir kuşatmanın İngiliz kuvvetlerini Halep'te korumasız bırakacağını düşünmekteydi. Ancak İskenderun'a ve Halep'e sahip olunması durumunda İngiltere için oldukça stratejik bir nokta düşmana karşı savunmada üstünlük sağlayabilirdi. Diğer yandan İskenderun'a sahip olunması durumunda Mezopotamya'daki Arap kabilelerinin silah ve cephane trafiğinin, İran Körfezi'nde olduğu gibi, Akdeniz'de de kontrol altına alınabileceğini düşünmekteydi. İskenderun'un İngilizlerin elinde olması, olağanüstü dönemlerde İngiltere'nin Mezopotamya'yı destekleyebilmesini sağladığı gibi olağan dönemlerde de burada mütevazi bir garnizon olarak görev yapmasının yeterli olduğu üzerinde duruyordu. İskenderun'a sahip olunmasının bu geniş sahillerin yönetiminde mali tasarruf sağlayacağını da eklemekteydi ${ }^{38}$.

İskenderun'un sürekli Mezopotamya hâkimiyeti için önemine değinen Kitchenar notanın devamında "O zaman neden Mezopotamya'yı almalıyız? sorusu ortaya çıkacaktır" demekte ve bunun gerekçelerini sıralamaktaydı. O'na göre Sina Çölü ile korunan Mısır'a kadar uzanan sınırları terk etmemek için Mezopotamya'nın ele geçirilmesi şarttı. Zira bu yapılmazsa bunu Rusya'nın er ya da geç yapacağını düşünmekteydi. Mezopotamya'nın Rusya tarafından ele geçirilmesi durumunda Rusya için İran Körfezi'ne bir kapı sağlayacağı gibi körfezdeki askeri gelişmeleri kontrol ve yine buradaki ticarette önemli bir pay kazandıracaktı. Diğer yandan Mezopotamya'nın hakimiyetinin İngilizlerde olmasının Arapların mukadderatı için önemli olduğunu düşünüyordu. Öyle ki bu bölgede kurulacak Arap Krallığı'nın İngiliz koruması altında olması durumunda, İngiltere'nin dünyanın en büyük Müslüman devleti haline geleceği ve bunun İslam alemi içerisindeki prestijlerini son derece arttıracağını belirtiyordu. Bölgenin tarımsal açıdan dünyanın en verimli yerlerinden birisi olduğunu vurgulayan savaş bakanı, Mezopotamya' nın İngilizlerin eline geçmesi ile çözüm bulunacak bir başka noktayı da açıklıyordu. Bölgede nüfusun oldukça seyrek olduğu ve "verimsiz arazilerin kolonizasyon için ideal alanlar" olduğunu ve bu sayede Hindistan'daki fazla nüfusun buraya kaydırılabileceğini planlamaktaydı. Böylelikle Hindistan Hükümeti'nin çok ciddi bir sorununa çözüm bulunmuş olacağını da eklemekteydi³9.

38 TNA, CAB, 24/1, 37-38, 16 Mart 1915, "Alexandretta and Mesopotamia, Memorandum by Lord Kitchener"

39 TNA, CAB, 24/1, 37-38, 16 Mart 1915, "Alexandretta and Mesopotamia, Memorandum by Lord Kitchener", 38-39. 
Ancak Kitchenar'ın tasavvurundaki planlar bununla da sınırlı değildi. O'na göre Mezopotamya'nın İngilizlere ait olması İran petrol kaynaklarının güvenliği açısından da önemliydi. Akdeniz'den İran Körfezine uzanan kara yolunun kontrolü -ki bu hat İngiltere'nin Hindistan'a ulaşan en hızlı ve en kestirme hattı olacaktı,- İngiltere'nin eline geçmesi bu sayede olacaktı. İskenderun'un kalıcı olarak işgal edilmesinin yeterli olmayacağını dile getiren Kitchener, İskenderun'a ilaveten Halep, Antep ve belki Maraş'ın da işgal edilecek alana katılmasının uygun olacağı düşünülse de mevcut Halep vilayetinin tamamının işgalinin uygun olmayacağını, yalnızca Adana vilayetinin doğu kısmının bu çizginin içerisine alınabileceğini belirtmekteydi. Kitchenar'a göre, İskenderun ve çevresindeki bu bölgenin ele geçirilmesi büyük güçleri buradan mahrum bırakmakla kalmayacak; diğer yandan da Akdeniz'den Mezopotamya'ya uzanan, İran Körfezi'nden Hindistan'a uzanan Bağdad demiryolu için doğal bir son durak olarak Akdeniz olabilecekti. İskenderun'un sahip olduğu mükemmel liman sayesinde, ulaşım ve ticari gemilerin uğrak yeri olacağını düşünmekteydi. Kitchener'a göre burada yapılacak büyük maliyetli liman çalışmaları ve tahkimat neticesinde İskenderun'a bir garnizon kurulması sayesinde İskenderun düşman saldırılarının hedefi olan bir yer değil Mezopotamya'nın müthiş doğal zenginliklerinden faydalanmak isteyenleri çekecek bir merkez haline gelecekti ${ }^{40}$.

İskenderun ve Mezopotamya'nın ele geçirilmesi için girişilecek operasyona bazı noktalardan itirazlar gelebileceğini söyleyen Kitchenar, bölgenin ele geçirilip tahkim edilmesinden sonra buradaki İngiliz birliklerinin ihtiyaçlarının bölgeden karşılanabileceğini düşünmekteydi. İskenderun'a Fransa'nın da Suriye mandası içerisinde sahip olmak istediğini yazan Kitchenar buranın Suriye'ye dâhil olmadığını ve bunu Fransızların da kabul edeceğini düşünmekteydi. Notasının sonunda Kitchener oldukça ilginç ve önemli düşüncelere yer vermekteydi; “... Ayrıca Afrika'daki Alman Kolonilerinin bir kısmı şu anda öngörüldüğüu kadarıla anlaşma yapıldığında Müttefiklere terk edilecektir. Bu Alman Afrikası... şüphesiz hangi devlet elinde tutarsa onun için değere sahiptir, ama onların değerini Ingiliz Imparatorluğu ile, İskenderun, Mezopotamya ile ve Bağdat demiryolu ile ve bütün bunlara sahip olunmasının Mısır'in ve Süveyş Kanalı'nın güvenliği ve bir o kadar da Hindistan'in güvenliği için olan değeri ile karşılaştırmak saçma olacaktır"4l. Kitchener'ın bu ilginç ve bir o kadar da dikkat çekici operasyon planı Hindistan Bakanı Marquess Crewe tarafından Hindistan Genel Valisi Hardinge'ye de oldukça gizli olarak gönderiliyordu² ${ }^{42}$.

Akademik Bakış 31 Cilt 7 Sayı 14 Yaz 2014

Diğer yandan İskenderun'un önemi üzerinde duran Kitchener ve Churchill'in dışında da bu fikri destekleyen askerlerin varlığı da dikkat çekicidir. Amiral Sir H.B. Jackson, tıpkı Kitchenar gibi Ulusal Savunma Komitesine

40 TNA, CAB, 24/1, 37-38, 16 Mart 1915, "Alexandretta and Mesopotamia, Memorandum by Lord Kitchener", s.39.

41 TNA, CAB, 24/1, 37-38, 16 Mart 1915, "Alexandretta and Mesopotamia, Memorandum by Lord Kitchener", s.40.

42 Cambridge University Library Archives, Hardinge Papers, (Bundan sonra HARDINGE)/121, No: 16. 
sunduğu bir raporunda İskenderun'un önemi üzerinde uzun uzun durmuştu. Jackson raporunda İskenderun'a atıfla “bu küçük ama eski Türk kasabası”nın gelecekte Doğu'nun politik ve ticari gelişmelerindeki öneminin artacağının açıç̧a ortaya çıktığını söylüyordu. Şimdiye kadar hiçbir önem arz etmeyen ve ilgilenilmeyen bu yeri bu denli önemli kılan nedenlerin neler olduğu üzerinde duran Jackson'ın raporunda özellikle, İskenderun Limanı'nın komşusu olan Suriye limanlarından ayıran fiziki özelliklerini sıralıyor, Almanya'nın yayılmacı politikasının bir sonucu olarak ortaya çıkan Bağdad demiryolunun İskenderun'un diğer potansiyellerini tamamlayıcı olacağını yazıyordu. Fransa'nın sahip olduğu Suriye sahillerinin jeopolitik önemi göz önüne alınarak İskenderun'un olası bir sorunda stratejik konumunun, İran'ın ve Fırat vadisinin güvenliği açısından hayati olacağını vurguluyordu. Amiral Jackson, gelecekle mevcut şartları birleştiriyor ve öngörülerde bulunuyordu. Ancak özellikle İskenderun'un Bağdat demiryolunun başında olması ve liman olarak fırtınalardan korunaklı her türlü sevkıyata elverişli olması gibi hususların yakın gelecekte sulama sayesinde öneminin iyice artacağını düşündüğü, Fırat vadisindeki ekonomik canlılığı da göz önüne alarak İskenderun'un mutlaka ele geçirilmesi gerektiğini vurguluyordu. Hatta Amiral uygulanabilirliği mühendislerin yanıt verebileceği bir şey dediği Fırat nehrini, Akdeniz'e bir kanalla bağlanması gerçekleşirse her türlü ticari emtianın taşınabileceğine dair planlarını da bu raporda zikrettiği görülmektedir. Burayı tam bir bağlantı noktası olarak gören Amiral, buraya en yakın alternatifin Beyrut olarak göründüğünü ancak Beyrut'un kaynaklarının İskenderun'a oranla çok daha sınırlı olduğunu da eklemekteydi ${ }^{43}$. Diğer yandan Ulusal Savunma Komitesi'ne sunulan İskenderun'un stratejik önemi üzerinde duran rapor bunlarla da sınırlı değildi. Bu komitenin sekreteri M.P.A Hankey tarafından sunulan raporda İskenderun Körfezi ve İskenderun'un konumu, pozisyonu, iklimi, kasabanın yerleşim yapısı, nüfusu, ticaret hacmi, su kaynakları, ankraj (demir atma) imkanı, liman imkanları, yollar, demiryolu sistemleri, telgraf bağlantıları ve İskenderun'un önemli merkezlere kaç mil uzaklıkta olduğu gibi oldukça stratejik ve önemli noktalar üzerinde duruluyordu ${ }^{44}$.

Akademik
Hemen hemen aynı günlerde yazılan bu iki yazıdan İngilizlerin tüm şartları zorlayarak İskenderun'a neden bir saldırı planladıkları anlaşılmaktadır. Bölgedeki çıkarlarını oldukça önemli gören Kitchenar, notası ile tüm İngiliz niyetlerini göz önüne sermektedir. Daha savaşın başında Osmanlı Devleti'nin bu coğrafyayı kaybedeceğini düşünen Kitchenar, İskenderun'a Osmanlı Devleti'nin stratejik bir noktasının ele geçirilmesi olarak bakmamakta, savaş sonunda oluşması muhtemel tabloları tahmin ederek İskenderun ve ona bağlı olarak Mezopotamya'nın ele geçirilmesinin önemini uzun uzun anlatmaktaydı. Diğer taraftan bu tasavvurlardan Osmanlı savaş erkânı da haberdardı. Hatta nere-

43 TNA, CAB, 24/2, 46-48, 18 Mart 1915, "Alexandretta, Its Importance as a Future Base, Remarks by Admiral Sir H.B. Jackson".

44 TNA, CAB, 24/1, 43-45, 17 Mart 1915, "Alexandretta, Note by the Secretary (M.P.A Hankey)" 
deyse Kitchenar'ın kabine üyeleri için hazırlandığı raporundaki fikirlerinden İngiliz savaş ekibinin içindeymişçesine haberdarlardı. Savaştan sonra anılarını yazan Ali Fuad Erden, harbin başında Kitchenar'ın Çanakkale için gerekli kuvvetten çok az bir kuvvetle İskenderun'a çıarma yapılabileceğine kesin bir inanç içinde olduğunu yazmaktaydı. Diğer taraftan Churchill'in Kitchenar'a yazdığı yazıda zikrettiği planın Enver Paşa'ya Avrupa'daki bilgi kaynakları tarafından aktarıldı̆̆ı görülmektedir. Enver Paşa'ya Viyana'dan Fuad imzasıyla gönderilen 24 Mart 1331 (6 Nisan 1915) tarihli telgrafnamede İngilizlerin Mısır'da topladıkları 400.000 kişilik ordularını, Türk ordusunun Ruslarla meşgul oldukları sırada İskenderun'a kaydırarak burayı ele geçirmeyi düşündükleri, bu sayede Irak ve Suriye'de bulunan orduları diğer "kuvve-i Osmaniye"den ayırmak istediklerini bildiriliyordu. Bu sayede aynı zamanda İngilizlerin Arabistan'ı diğer "Müslüman Osmani'den" ayırmak niyetinde olduğu belirtiliyordu ${ }^{45}$. Hatta Churchill'in Kitchenar'a yazdığı 20 Ocak 1915 tarihli mektubunda dile getirdiği üzere eğer Çanakkale istihkâmları İngiliz donanmasını çok zorlarsa ve geri çekilmek durumunda kalınırsa aynı anda başlatılan İskenderun harekâtı sayesinde asıl harekâtın İskenderun üzerine yapıldığı iddiası ortaya atılacak ve bu sayede İngiltere'nin Şarklı halklar üzerinde imajının sarsılmasına engel olunacağı yönündeki düşüncesini Erden'in hatırlarında aynen görmek ilginçtir. Erden şöyle diyordu, "Bunlar, Çanakkale istihkâmların tahrip ve geçilemeyecek derecede kuvvetli olduğu anlaşılırsa, buradaki harekâtın ìskenderun sahnesine naklolunabileceğini düşünüyorlardl ${ }^{46}$. Durumun farkında olan Osmanlı idarecileri mevcut şartlar içerisinde mümkün olan tedbirleri alıyorlardi ${ }^{47}$.

Ancak öyle anlaşılıyor ki, Rusya'nın eline geçecek İstanbul ve Boğazlar ile Suriye'ye gözünü dikmiş olan Fransa'nın gelecekte hasımları olacağı düşüncesi ile oldukça stratejik bir nokta olan İskenderun'a Çanakkale ile eş zamanlı olarak bir saldırı yapılması fikrinde ısrar eden İngiliz başkumandanı ve diğer yetkililerin aksine bazı yetkililer bu hareketin Kitchener'ın hesabından farklı sonuçlar doğurabileceğini düşünüyorlardı. İngiltere'nin doğudaki sömürgeleri açısından en önemli isimlerinden birisi olan Hindistan Genel valisi Hardinge yazdığı bir memorandumda İskenderun'un ele geçirilmesinin oldukça stratejik bir noktaya hakim olmak anlamına gelmesine rağmen öncelikle böylesi bir operasyonun zorlukları düşünülmeli diyor ve ardından da Fransız Suriyesi sahasına giren İskenderun'un Rusya'nın Ermeni sahasına da girdiği göz önüne alındığında İskenderun'un, İngiltere'yi zaman içinde her ikisiyle de karşı karşıya getirebileceğini yazıyordu ${ }^{48}$.

45 Genelkurmay Başkanlı̆̆ı, Askeri Tarih ve Stratejik Etüt Dairesi Başkanlığı Arşivi/Ankara (Bundan sonra ATASE), K: 448, D: 1767, F: 47, 24 Mart 1331 (6 Nisan 1915).

46 Ali Fuad Erden, Birinci Dünya Savaşı́nda Suriye Hatıraları, (Yay. Haz: Alpay Kabacalı), Türkiye İş Bankası Yay., İstanbul 2006, 172.

47 Osmanlı Devleti'nin aldığı tedbirlere ilgili başlıkta değinilecektir.

48 TNA, CAB, 24/1, 3 Mart 1915, "Notes and Private telegram from the Viceroy regarding the future settlement of Eastern Turkey in Asia and Arabia", s. 51

Akademik Bakış 33

Cilt 7 Sayı 14 Yaz 2014 


\section{İngiliz Gemilerinin Taciz Saldırıları}

Çanakkale'deki bir organize saldırının ne zaman ve ne şekilde yapılacağına karar verilmediği günlerde İngiliz gemilerinin İskenderun sahillerine saldırıları devam ediyordu. Fransız askeri ataşesinin Fransız Deniz Kuvvetleri Bakanlığına gönderdiği telgrafta İskenderun'daki Türk Kumandandan şu bilgileri Philomel isimli gemiye bildiriyordu:

"Suriye'deki Imparatorluk Ordusu /Osmanlı Ordusu/ Genel Komutani'nin emriyle sizi bilgilendirmek isterim ki, 11 Ocak'ta "Doris"kruvazörü herhangi bir askeri neden olmaksızın İskenderun sahilindeki Utuguene köyünü bombalamıştır ve bombardıman sırasında iki küi̧ük kız, bir kadın ve bir erkek ölmüş, yaralı beş diğer kişi de dâhil tüm masum sivil halk için Imparatorluk Hükümeti karar vermiştir ki, bu harekete misilleme olarak uluslararası anlaşmaların aksine olarak ilkin ingiliz vatandaşlarının arasından vurmak için Halep'in Köyünde tutuklu olan Ingiliz vatandaşlarından beş kişi tesadüfen seçilmiştir, ikinci olarak hayattaki yaralı beş kişinin zararına karşılık her birine 100 Türk Lirası değer toplamı Ingiliz vatandaşların mal-mülklerinin müsaderesi ile karşılanacaktır"49.

İskenderun kumandanının gönderdiği bu uyarı Cemal Paşa'nın 12 Ocak 1915'te gönderdiği emirle alakalıydı. Buna göre Cemal Paşa İskenderun'daki Kolordu Kumandanına İngiliz kruvazörünün bombardıman ettiği köyde veya civarında mevzide, yürüyüş veya ikamet halinde asker olup olmadığını yahut

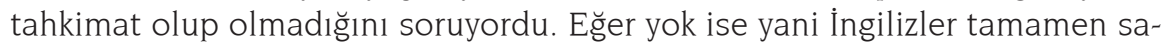
vunmasız köyleri sebepsiz yere bombardıman ediyorsa Kolordu kumandanına İngiliz zırhlısı Philomel'e yukarıda gönderdiği telgrafta belirtilen hususların uygulanması emrini veriyordu. Cemal Paşa'nın emirnamesi Ali İhsan Sabis'in bildirdiğine göre, şu şekildeydi: "Bu köyde kaç insan şehit olmuşsa Halep veya Şam'da mevkuf bulunan Ingiliz tebaasindan o kadar Ingiliz lalettayin/tesadüfen/ tefrik edilerek muhafaza-i kaviyye altında, bombardıman edilmiş olan köye sevk edilecek ve orada, masum insanları öldüren Ingiliz mermilerinin düştüğ̈̈ noktada kurşuna dizilecektir. Herhalde bunlar erkekler arasindan intihap edilmelidir. ${ }^{150}$.

Akademik
Ali İhsan Sabis'in "benzer benzerle tedavi edilir" sözüyle anlamlandırdı̆̆ı bu sert uyarıya karşılık Philomel'in kaptanından İskenderun kumandanına şu cevap gelmişti: "Türk Hükümeti'nin bazı Ingiliz vatandaşlarını öldürme kararı aldığına dair bizi bilgilendirmek üzere gönderdiğin mektubunu aldık ve Deniz Kuvvetleri Bakanlı̆̆ı'nı bilgilendirdik. Bu meyanda Suriye Genel Komutanını lütfen bilgilendirin ki, eğer tehdit ettiği şekilde davranırsa O ve kelimelerle anlatılması güç bu harekette O'na katılanlar hayatlarını tehlikeye atmış olacaklardır... ${ }^{151}$.

Cemal Paşa'nın bu sert tehdidi İngiliz gemilerinin İskenderun Limanı'nı sivilleri hedef alarak giriştikleri saldırılara son vermelerinde etkili olmuştur.

49 CHAR 13/67,48, 11 Şubat 1915

50 Sabis, a.g.e., s. 12

51 CHAR, 13/67, 49, 11 Şubat 1915. 


\section{İskenderun'a Saldırı Planı ve Taktikleri}

Ocak ayı başlarında İngiliz askeri makamları çıkarmanın askeri plan ve projesini ortaya koymuşlardı. Buna göre planın hedefi, muhtemel zorluklar, kuvvetlerin ihtiyaç duyacağı malzemeler, İskenderun'un ele geçirildikten sonra savunmasının ne şekilde yapılabileceği bir raporla ortaya konmuştu. Raporun içeriğinden hemen yapılacak bir harekâtın planı olduğu anlaşılmaktadır. Rapordaki tespitler şu şekildeydi:

1- Planın hedefi: İskenderun ve çevresine yeterli miktarda bir kuvvet yerleştirmek, burayı operasyonlara ve demiryollarına ve Suriye ve Anadolu arasındaki telgraf hatlarına hareketli saldırılar düzenlemek için güvenli bir merkez haline getirmek. Saldırılar neticesinde İskenderun'un ele geçirilmesinin sonucu olarak bu çevredeki Ermeni nüfusu ${ }^{52}$ Türk yönetimine karşı isyan edecektir.

2- Muhtemel savunma: İskenderun'da şu anda mevcut birlik sayısı bilinmemektedir. Birliklerin buradan zaman zaman Suriye ordusuna yönlendirildiği rapor edilmektedir ama son duyumlara göre denizden bir indirme hareketine karşı küçük bir garnizon bulundurulduğunu işaret etmektedir ${ }^{33}$.

İngilizlerin aldığı duyumlara göre yaklaşık altı hafta önce Avrupa Türkiyesi'nden silahların buraya bölgesel savunma için ulaştığı rapor edilmişti. Öngörüye göre eğer garnizon zayıfsa muhtemelen Belen ${ }^{54}$ geçidine çekilecekti, buradan hareketle Süveydiye'den bir çıkarma hareketi yapılabilirdi. Fakat bu operasyonun çıkarmanın zorluğu nedeniyle kolay olmayacağı düşünülmekteydi. Yolun kötü ve mesafenin yaklaşık 40 mil kadar olduğu hesaplanıyordu.

Bölgede toplanabilecek Türk kuvvetlerine dair öngörülere göre müsait şartlar olursa V. Kolordunun (corps) 30.000 kişisinin Eskişehir demiryoluyla İskenderun'a yaklaşık on günde getirilebileceği düşünülmekteydi. İzmir'de bulunan IV. Kolordu'nun iki tümeninin de buraya aynı zamanda getirilebileceği ama çok sayıda askerin İzmir bölgesinde polis görevi için gerektiğinin göz önüne alınması gerektiği belirtilmekteydi. Diğer taraftan IV. Ordu'nun 20.000 askerinin Lübnan'dan Belen Geçidi'ne İngiliz kuvvetlerinin çıkarma yapmasından (Halep'ten İskenderun 96 mildir) yaklaşık on gün içerisinde ulaşabileceği düşünülmekteydi. İskenderun'a çıkarma yapan kuvvete çıkarma hareketinden on gün sonra 50.000-60.000 kişilik bir kuvvet ve 90 silahla saldırılabileceği

Akademik Bakış 35 Cilt 7 Sayı 14 Yaz 2014

52 Ermeni milliyetçilerinin önderlerinden Mısırlı Bogos Nubar Paşa ile bir görüşme yaptığını bildiren İngiltere'nin Kahire'deki Yüksek Komiser vekili Cheetham daha 12 Kasım 1914'de Kilikya'da yaşayan Ermeni halkın Osmanlı ile herhangi bir şekilde anlaşma yapmasının mümkün olmadı̆̆ını ve bu halkın İtilaf kuvvetlerinin İskenderun, Mersin ya da Adana'da karaya çıkma girişimine yardım etmek için gönüllü olduklarını bildiriyordu; The Arab Bulletin, Bulletin of the Arab Bureau in Cairo, 1916-1919, Vol. I (1), London 1986, s. 15.

53 TNA, FO, 371/2146, 70404/257, 12 Kasım 1914, Cheetham'dan Edward Grey'e.

54 Amanos Dağları arasından Antakya'yı İskenderun'a bağlayan geçittir. 
hesaplanıyordu. Ayrıca Misis yolu mobilize kuvvetler tarafından indirme hareketinden hemen sonra yok edilmezse, buradan getirilecek Türk askerlerinin saldırısının bir ya da iki gün erken beklenebileceği bildiriliyordu. Rapor göre Kilikya kapısından geçiş (ki burada demiryolunda bir boşluk vardır) Ocaktan Mart sonuna kadar geçen süreçte küçük bir jandarma grubu olsa bile kar ve havanın normal zorlukları nedeniyle oldukça zor bir operasyondur. Yılın diğer zamanlarında bu yürüyüşün iki gün alacağı da ekleniyordu.

3- Kuvvetin ebat ve yapısı olarak tüm rütbelerden toplam 21.000 rakamı veriliyordu. Diğer taraftan kuvvetlerin dağılımı şu şekilde belirtilmektkeydi:

a- İskenderun'u ve Belen Geçidi'ni ele geçirmek için: 3 piyade tugayı, 4 dağ bataryası, 4 adet 4.7 inclik silah, 1 sahra piyade birliği, 1 Howitzer bataryası, 1 muhabere bölüğü, 3 tayyare. b- hareketli saldırılar için ilave (kuvvet) 3 süvari alayı ya da Yeomanry birliği, 1 piyade tugayı, 1 bisikletli bölük. c- Katır nakliye, d- sahra fırın bölüğü, e- sahra ambulansları, f- savaş gereçleri, veteriner ve diğer bölümlere ait detaylar.

4- Kuvvetlerin barınmasına dair planlar ise şu şekilde sıralanıyordu: 16.000 kişi için çadırlar gerekmektedir. İskenderun'da (12.000 kişi ikamet etmektedir) 5.000 kişiye konaklama sağlanabilir. Belen geçidi yakınlarında kamp yapılabilir gibi görünmektedir. Savunmayı yapacak birlikler için bazı formdaki barakalar zaman içinde yapılacaktır. Ocak, şubat ve mart ayları boyunca yoğun yağışlar ve soğuk rüzgârlar bu barınakları tüm kuvvetler için gerekli kılmaktadır.

5- Sefer planı şu şekilde sıralanıyordu: a- İskenderun'a ani bir indirme hareketi Ayas ${ }^{55}$, Burnaz ve Payas'a yapılacak eş zamanlı çıkarma ile birlikte gerçekleştirilebilir. Bundan sonra mümkün olduğunca hızlı şekilde Belen Geçidi'ni ele geçirmek için devam edilmelidir ki bu harekâtın istikbali ve kuzey, güney ve doğu İskenderun hattının savunması için temeldir. Geçidin en yüksek noktası olan iki köprünün (vadilerin üzerinde) kapatılması yani bu köprülerin yok edilmesi ile düşman Halep'e ilerlemekte ciddi anlamda gecikecektir. Geçidin en yüksek noktası kasabadan yaklaşık 12 mil uzaklıktadır. b) Misis'de (Adana'nın doğusunda) demiryolunun imha edilmesi Türkleri demiryolu hatlarının 200 milinden mahrum bırakacaktır. Misis Ayas'dan karayoluyla yaklaşık 20 mil uzaklıktadır ve demiryolu köprüsünün imha edilmesi operasyonu büyük zorluklar içermemektedir.

Halep yakınlarındaki demiryolu ve telgraf hatlarının tahrip edilmesi için muhtemelen bir mobil 3 dağ alayı, bir piyade alayı ve 2 dağ bataryasına ihtiyaç vardır. Eğer hissedilir bir mukavemet görülmezse gidiş ve dönüş yolculuğu yaklaşık bir hafta alacaktır. Eğer Belen Geçidi'nin güvenliğinin sağlanması hemen gerçekleştirilebilirse Lübnan'daki Türk kuvvetlerinin Halep'in kuzeyinde toplanması riski daha az olabilir.

6- İskenderun'un savunması için düşünceler şu şekilde sıralanıyordu:

55 Bugün Yumurtalık ilçesidir. 
a- Kasabanın güneyindeki yaklaşık 200 feet yüksekliğindeki tepe ve kasabadan 1 mil uzaklığa kadar olan bölge kasabanın savunması için uygundur. Dört adet 4.7'lik silahla, bir howitzer topu, üç sahra topu bataryaları bir piyade tugayı alanın güvenliğini sağlayacaktır.

b- İskenderun çevresindeki Amanos Dağları, Belen yolu ve İskenderun Körfezi'nden doğuya doğru geçen dört hat tarafından kesilmektedir. (Haritaya göre). Kasabaya ayrıca Payas sahil yolu ve Tarsus'tan gelen sahil yolu ulaşmaktadır.

Yılın bu periyodunda Belen Geçidi'ni tutmaya muhtemelen iki tabur asker ve iki dağ topçu bataryası yeterlidir ama dağ üzerindeki hatlar geçilebilir hale gelir gelmez buraları tutmak için iki ilave batarya ve ilave iki dağ topçu bataryası gerekmektedir. Belen'in kuzey ve güneyindeki Daz Dağı, Nur ${ }^{56}$ Dağ'ın en yüksek noktalarını sırasıyla tutmak gerekmektedir bu harita çalışması ile belirlenemez.

Belen Geçidi ile kasabanın iç savunmaları arasında muhtemelen orta yükseklikler vardır, bu noktaların destek noktaları olarak ele geçirilmesi zorunludur.

7- Birlikler için gereken özel kıyafetler hakkında planda şunlara yer veriliyordu:

Kışın şiddeti ve Belen Geçidi'ndeki muhtemel kar yağışı nedeniyle özel sıcak tutan kıyafetler gerekecektir. Ocak ve Şubattaki kuvvetli yağışlar için de kıyafetler üretilmelidir.

8- Yaralıların tedavisi için kurulması gerekli olacak merkezi hastane hakkındaki fikirler şöyle sıralanıyordu:

Hasta ve yaralılar için bir merkezi hastanenin Kıbrıs'ta olması elverişli olacaktır. İskenderun'dan uzaklığı 160 mildir ${ }^{57}$.

\section{İskenderun'un Savunması için Osmanlı Devleti Tarafından Alınan Tedbirler}

Savaşın başladığı günden itibaren böylesi bir harekatın gerçekleşmesi ihtimali Osmanlı idaresi tarafından tahmin ediliyordu. Bu bağlamda bazı askeri tedbirler alındı. Amanos Dağlarının savunmaya elverişli ve çıkarmayı zorlaştırıcı etkisi de göz önüne alınarak Mersin Limanı, Yumurtalık ve İskenderun Körfezi'nde en uygun çıkarma yapılacak yerin Payas olacağı anlaşılabiliyordu. IV. Orduya bağlı VI. Kolordu Halep'te konuşlandırılmış ve İskenderun'un savunması da bu kolorduya bırakılmıştı. Kanal harekatı düzenlemeleri çerçevesinde XII. Kolordu İskenderun'a kaydırılmıştı. II. Ordu müfettiş̧liği bölgesindeki kolorduların yardıma gitmesi Musul ve Bağdat kolordularından buraya kuvvet verilmesi kararlaştırılmıştı. Cemal Paşa'nın IV. Ordu Kumandanlığı'na atanmasının ardından Mersin-İskenderun arasındaki kuyuların korunması XII. Kolordu'ya, Payas'tan güneye doğru sahil ise; VI. Kolordu'ya havale edilmişti. Cemal Paşa, İskende-

56 Belgede Naulu Dagh olarak geçmektedir.

57 TNA, WO 106/1570, 11 Ocak 1915, "Expedition to Alexandretta" 
run'daki savunma kuvvetini yetersiz bulunca XII. Kolordu'dan İskenderun'a bir dağ bataryası ile bir piyade alayının gönderilmesi emredilmişti. Bu kuvvetlerin VI. Kolordu'nun emrinde bulunmasını, İskenderun'da sahra mevziinin hazırlanmasını da VI. Kolordu Komutanlığı'na bildirmişti. Enver Paşa Ağustos 1915'te VIII. Kolordu'nun bir fırkasının Adana civarına naklini istemiş, Toros ve Amanos bölgesinin korunmasını emretmişti. Aralık 1915'te Çanakkale harekâtından çekilmelerinin ardından Enver Paşa IV. Ordu Komutanlığı'na İskenderun bölgesinde yapılması muhtemel bir çıkarmaya karşı gerekli tedbirlerin alınması istenmişti ${ }^{58}$. Diğer taraftan Arapların -İngilizlerin de kışkırtmalarıyla- bölgedeki savunmayı zora sokacak bir harekete girişmelerinden şüphelenen Cemal Paşa, Araplardan kurulmuş olan 25. Tümeni Çanakkale savaşlarına katılmak üzere Haziran 1915'de Gelibolu'ya gönderdi. Ardından dört tümen daha Gelibolu'ya gönderildi diğer Araplardan oluşan birlikleri de bölgeden uzaklaştırmanın hazırlıklarına girişti. İtilaf devletleri tarafından çıkarma dahil her türlü faaliyetlerin planlandığı bir aşamada halkın da savunmaya iştiraki için İskenderun'da milis teşkilatı için hazırlık yapılmıştı. İskenderun-Payas-Misis telgraf hattının düşman filoları tarafından bombardıman edilip iletişimin sık sık kesintiye uğramasından ötürü denizden daha içlere alınmasına çaba gösterildi. Benzer şekilde İskenderun'dan geçen posta ve evrak nakliyatı hususunda çalışma yapılmıştı. İskenderun ile Halep arasındaki yolun nakliyat için elverişli hale getirilmeye çalışılması yanında İskenderun-Payas tren yolunun zaman zaman yapılan bombardımanlardan korunması için demiryolu binalarının sadece mecbur kalındığı hallerde kullanılması istenmişti.

Diğer taraftan savaşta kullanılmak üzere Başkomutanlık Vekaleti'nin isteği doğrultusunda İskenderun Belediyesi'ne ve Halep yol inşaat şirketine ait dekovil malzeme ve vagonlarının Tekâlif-i Harbiyeye göre devlet tarafından el konulması kararlaştırılmıştı. Bunun yanında İskenderun'da bulunan ve ülke açısından büyük öneme sahip bulunan İskenderun'daki bakır madeninin emniyeti sağlanmaya çalışılmış yaklaşık 540.000 kilo bakır önce Adana'ya oradan da İstanbul'a sevk edilmişti. Osmanlı sahillerinde bulunan zahire her türlü ihtimale karşılık İstanbul'a sevk edilmişti. Kıymetli eşya, evrak ve para ayrıca şimendiferlerin ihtiyacı olan cardiff cinsi 473 ton kömürün de iç bölgeye gönderilmesi alınan tedbirlerdendi. Ayrıca savaşa Osmanlı Devleti'nin dahil olmasından hemen sonra İskenderun'daki düşman devletlerin vatandaşları buradan uzaklaştırılmıştı. Diğger yabancı uyruklular da dikkatle takibe alınmış, bazı misyoner kolej ve manastırların kapatılması kararlaştırılmıştı. Bunun dışında bütün Ermeni fırkalarının iştiraki ile Ermeniler tarafından yapılması planlanan ihtilalin Dörtyol'da başlatılacağı Osmanlı Hükümeti tarafından öğrenilince mahalli yöneticilerin teyakkuz halinde olmaları bildirilmişti ${ }^{59}$.

58 Ali Arslan, “İngilizlerin İskenderun'u İşgal Projesi ve Osmanlı Devletinin Aldığı Tedbirler (19141915)", IV. Hatay Tarih ve Folklor Sempozyumu, Antakya 1997, s. 11-12.

59 Arslan, a.g.m., s.11-24. 
Özellikle bu son tedbirin alınması için birçok gerekçe vardı. Sadece bölgede yaşayan Ermeniler değil Amerika'daki Ermenilerin oluşturduğu komiteler İngiliz Dışişleri Bakanı Edward Grey'e yazdıkları yazılarla yapılacak bir harekâtta aktif rol alabileceklerini bildirmişlerdi ${ }^{60}$.

\section{Operasyondan Vazgeçilmesi}

Sık sık İngiliz ve Fransız gemileri tarafından taciz edilen İskenderun Limanına Kitchenar'ın, Churchill'in ve Sekreter Hankey'in düşündüğü şekliyle ve Çanakkale Boğazına yapıldığı gibi bir operasyonun düzenlenmesi noktasında Özellikle Fransız Deniz Kuvvetleri'nin kuşkuları vardı. Amiral Pearse'ın "Eğer iskenderun'un ele geçirilme niyeti varsa bunun geciktirilmeksizin yapılması" yönündeki teklifine Fransız Deniz Kuvvetlerinden verilen cevapta aynı anda birkaç askeri operasyona girişmenin tehlikeli ve zor olacağı uyarısında bulunulmuştu ${ }^{61}$. Fransa'daki İngiliz Askeri ataşesine verilen bu cevap İngiliz Deniz Kuvvetlerine "[Fransız] Deniz Kuvvetleri İkenderun'a operasyon yapılmasına izin vermemiştir" şeklindeki kısa ve net bir telgrafla bildiriliyordu ${ }^{62}$. Ancak İskenderun Limanı'nın gözlemlenmesine devam ediliyordu. Hatta bölgedeki görev taksimatında bu görev Fransız Deniz Kuvvetlerine devredilmişti. Amiral Dartige yönetimindeki Bucchante isimli kruvazörün İskenderun'u izlemesi görevi için bırakıldığı anlaşılmaktadır ${ }^{63}$. Diğer taraftan zaman zaman İskenderun'a yeni bir askeri saldırı fikri gündeme gelmiştir. 15 Kasım 1915'de Paris'teki İngiliz elçisi Bertie'den gelen telgrafa göre, Paris'teki İngiliz Askeri Ataşesi, Savaş Bakanı ve General Grazieni ile Doğu Akdeniz' de yeni bir operasyonun uygunluğunu tartışmışlardı. Fransız Savaş Bakanı'na göre Fransa hâlihazırda pek çok cephede savaştığından bunlara bir yenisinin daha eklenmesi ihtiyatsızlık olarak görülmekteydi. Hatta Bertie'nin bildirdiğine göre General Murray da Fransız Savaş Bakanı'nın görüşünü paylaşıyordu ve Kitchener'ın önerilerini desteklemiyordu. Fransız Savaş Bakanı'nın Kitchenar'ın fikirlerini paylaşmadı̆̆ 1 da açıktı ${ }^{64}$. Diğer taraftan Kasım başlarında heyetiyle yola çıkan Kitchener 10 Kasım'da Mondros'a gelmişti ${ }^{65}$. Mondros'tan gönderdiği telgrafında Fransa'nın duygusal itirazları ile İskenderun'a yapılması düşünülen operasyonundan vazgeçilmesinin savaştan sonra "Istanbul'un Rusya ya ödül olarak verilmesi ve Suriye'nin Fransa'nın faydasına olarak uygun sinırlarla paylaştırılmasının takip edeceği iyi bir emsal olup olmayacağı" sorusunu soruyordu. Bu nedenle İngiltere'nin operasyonlara devam etmesinin gerekliliği üzerinde duruluyor ve gelecekte İngiltere'yi Fransa'nın korumayacağını hatırlatıyordu. Bu kısa ama oldukça net telgraf derhal Paris'teki İngiliz elçisi

Akademik Bakış 39 Cilt 7 Sayı 14 Yaz 2014

60 TNA, FO 371/2485, 41444, 23 Mart 1915, Armenian National Defence Committee of America [Amerikan Milli Ermeni Savunma Komitesi]'dan Edward Grey'e.

61 CHAR, 13/67, 51, 19/20 Şubat 1915

62 CHAR, 13/67, 52, 22 Şubat 1915

63 CHAR, 13/67, 54, 25 Şubat 1915

64 TNA, FO 371/2480, 170326/875, 229, 15 Kasım 1915, Lord Bertie'den Dişişleri Bakanlığı'na.

65 C.R. Ballard, Kitchener, Newnes, London, bty, s. 390 
Bertie'ye gönderildi $^{66}$. Ayrıca Dışişleri Bertie'ye gönderdiği telgrafta her iki ülke Genelkurmayının bir araya gelerek bir toplantı yapması ve bunu müteakiben her iki ülke kabinesinin bakanlarının bir araya gelmesinin mümkün olan en yakın tarihte gerçekleştirilmesinin gerekliliğini bildirdi. Bertie'ye Fransız Bakanlarla herhangi bir yerde ve zamanda toplanmaya razı oldukları da yazılmışt1 ${ }^{67}$. Bu fikir Fransız kabinesince kabul edilmiş ve bu toplantının Paris'te yapılmasının daha faydalı olacağı bildirilmişti ${ }^{68}$.

Ancak bu telgrafın gönderilmesinden hemen sonra İngiliz Savaş Bakanlığı'nda İngiliz ve Fransız yetkililerin yer aldığı bir toplantı gerçekleştirildiği anlaşılmaktadır. Toplantıda hazır bulunan görevliler şunlardı: Korgeneral Sir Archibal Murray, Londra'daki Fransız Askeri Ataşesi Albay de la Panounse, Kaptan Doumayrou, Fransız deniz ataşesi Kaptan de Vaisseau de Sainte Serne, Yüzbaşı de Vaisseau Durand Viel, Tümgeneral Kiggell, Kaptan Deniz kuvvetleri savaş personeli personelinden sorumlu, operasyonlar yardımcı direktörü H.W. Grant, Kaptan Earl Percy. Bu toplantıda göz önüne alınan, dile getirilen görüşler raporda maddeler halinde kaydedilmişti. Askeri konulara ilişkin ifadeler bu bağlamda oldukça ilginç ve dikkat çekicidir. Kitchener'in teklif ettiği şekliyle İskenderun'a asker çıkarılması planının nihai kararının verilmesinden evvel Fransız Genelkurmayı ile şu konuların dikkatice değerlendirilmesi ve tartışılması isteniyordu:

1- Mekan Türklerin geniş miktardaki kuvvetleri toplaması ve yerleştirmesi için uygun görünmektedir. Eğer İtilaf kuvvetleri arasında en üst seviyede gizlilik korunmazsa ilk çıkarmaya 15.000 kişilik bir kuvvetle mukavemet edilebilir. Ondan sonra da üstün Türk kuvvetlerinden güçlü saldırılar beklenmelidir.

2- İtilaf kuvvetlerinin hedefine ulaşması için yaklaşık 25 mil içerisine kadar zorlanmalıdır. Bundan sonra savaşın geride kalan sürecinde tüm saldırılara karşı 50 mil civarındaki çevresi tutulmalıdır. Bunun için en azından 160.000 piyade gerekeceği tahmin edilmektedir.

3- Çarpışmadan, soğuk ve açıkta kalmaktan kaynaklanan kayıpların telafi edilmesi kuvvetlerin mukavemetli biçimde tutulması, yeni asker alımı gerekebilir. Bu alım ilk üç ay için mevcut birliklerin \% 20'si oranında, bundan sonraki her bir ay \% 15'i oranında tahmin edilmektedir.

4- Kuvvetlerin büyük giderleri savunma amacını da kapsamaktadır. Çok büyük ihtimalle herhangi saldırıya girişilmeyecektir. Bu operasyon ana savaş alanında Almanya'yı zayıflatmayacaktır, oysaki Fransa'daki kuvvetlere ait aynı miktardaki harcama en azından eşit ölçüde Almanları zayıflatması beklenebilir.

66 TNA, FO 371/2480, 172415/56, 248, 17 Kasım 1915, Lord Kitchener'dan Dışişleri Bakanlığı'na.

67 TNA, FO, 371/2480, 2612, 244, 14 Kasım 1915, Dışişleri Bakanlığından Lord Bertie'ye.

68 TNA, FO, 371/2480, 277, 246, 14 Kasım 1915, Dışişleri Bakanlığından Lord Bertie'ye. 
5- Sırbistan ve Çanakkale'den sonunda çekilinse bile geri çekiliş zaman alacaktır ve bir süre için bu üç bölgede birden meşgul olunacaktır. Bu deniz ve kara kuvvetlerinin tehlikeli biçimde saçılmasına sebep olabilecektir.

6- Önerilen şekliyle her hangi bir kuvvetin nihai çekilişi kesinlikle zor olur. İmkânsız da olabilir, bu durumda kuvvet Almanlara karşı savunma için hiçbir zaman kullanışlı olmayabilir.

7- Müttefiklerin stratejilerinin temel prensibi savaş alanının belirleyici bir alanında ve uygun zamanda kullanmak üzere olanca kuvvetin büyük bir saldırı için tutulması olmalıdır.

Şimdiye kadar gerekli olur diye mevcut kuvvetin tutulmasına devam edilmesi esas operasyon bölgesi dişındaki bölgelerdeki girişimlerin limitlerinde tereddüde düşülmemesi gerektiği vurgulanıyordu ${ }^{69}$.

İskenderun'un Ayas Körfezi'ne çıarma yapılması ile ilgili Deniz kuvvetlerinin düşünceleri de harekâtın içerdiği zorluklar üzerinde yoğunlaşıyordu. Bu bağlamda Körfez'in Türk kuvvetleri için uygun savunma şartları üzerinde duruluyordu. Ayas Körfezi'nin hava koşullarından mükemmel şekilde korunduğu ve gemiler için uygun bir liman olması karşısında fileler sayesinde deniz altılarla korunabildiği üzerinde duruluyordu. Yaklaşık 4,5 millik ağ ve buna ilaveten çok sayıda küçük geminin ağı desteklemek için körfeze demirlemesi gerektiği belirtiliyordu. Körfezin kuzey kıyısını çevreleyen dağlarda mevzilenmiş silahlardan açılan ateşten tepeler ele geçirilmedikçe ve birlikler tarafından tutulmadıkça kurtulmak mümkün olmadığı ve limanın güvende olmayacağı açıklanıyordu. Körfez çevresinin sı ̆̆ olması yanında, silahları, atları ve diğer cephaneyi indirmek için iskele ve diğer imkânların olmadığı ekleniyordu. Buna karşılık buradaki iskelelerin mavnalar için uygun olabileceği ve gerekli teçhizatın üretilecek mavnalar ile sevk edilmesi gerektiği belirtiliyordu.

Diğer taraftan Gelibolu Yarımadası tahliyesinden evvel Ayas Körfezi'ne sefer yapılması önerisi yapıldığı ancak tüm küçük tekne ve mavnaların Gelibolu Yarımadası'nın tahliyesi için gerekli olduğu hatırlatılıyordu. Ayrıca tüm mavna, römorkör ve küçük tekneleri Mondros Limanı'nda toplamanın aylar aldığı ve Ayas Körfezi için benzer bir hazırlığın uygun gemiler bulma ve kışın onları İngiltere dışına çıkarma zorlukları nedeniyle birkaç ay alacağı belirtiliyordu. Akdeniz'de 3.000 milin üzerinde olan nakil rotalarının destroyer, silahlı trol tekneleri ve küçük devriye teknelerinin azlığı nedeniyle denizaltılara karşı seyrek biçimde korunduğu, buna ilaveten Ayas Körfezi'ne yeni bir seferde mükemmel biçimde korunan 400 millik bir mesafenin var olan rotaya eklenmesinin gerektiği vurgulanıyordu. Bunu yapmak için yeni gemiler temin edilemeyeceği gibi Çanakkale'nin boşaltılmasının müttefik deniz kuvvetlerinin işini kolaylaştırmayacağını zira bu kuvvetlerin büyük gemileri denizaltılardan korumak için gerekli olduğu ve denizaltıların Boğazlara girişini engellemek için ihtiyaç du-

69 TNA, WO 106/1570, 11 Ocak 1915, "Expedition to Alexandretta-Statement of Military Considerations", s. 2. 
yulan geniş çeşitlilikte destroy ve küçük gözlem teknelerinden oluştuğu belirtiliyordu. Tüm bu külfetine rağmen sonuç olarak Deniz kuvvetleri ilgilendiği müddetçe Ayas Körfezi'ne bir çıarma seferine girişilmesinin mümkün olduğu açıklanıyordu. Eğer Deniz kuvvetlerinin Çanakkale harekatı, Selanik harekatı, Mısır'ın savunması, Akdeniz'deki ulaşımın korunması, Fransa'daki ordunun deniz iletişim hatlarının korunması, Amerika Birleşik Devletleri'nden cephane ulaşımında kullanılan hatların korunması, Adriyatik için ayrılan İngiliz kuvvetlerinin ve cephane ile Archangel'e (Arkhangelsk) ulaşacak gemilerin korunmasında kullanılan hatların güvenliği için gerekli kaynaklar üzerinde büyük bir mali yük getirmeyecekse bu harekatın yapılabileceği belirtiliyordu. Tüm bu görevlerin Alman Donanmasının kuzey denizini terk etmesini önlemek görevi ile uyumlu bir şekilde yürütülmesi gerektiği düşünülüyordu ${ }^{70}$.

Sıralanan askeri güçlükler ve itirazlar konusunda İngiliz Savaş Bakanı Kitchener'ın verdiği cevapta harekatın uygulanabilirliğine dair şu noktalar üzerinde duruluyordu. Kitchener Doğu Akdeniz'deki İngiliz İstihbarat Karargahı ve General Monro'nun (Charles Monro) burayı koruyacak Türk kuvvetinin 5.000 kişiyi aşamayacağını ve iletişim zorlukları nedeniyle burada 15.000 kişiden fazla kuvvet sevk edemeyeceklerini ve bu sayıyı sabit tutmalarının oldukça zor olduğunu söylemişti. Lokal olarak düşünüldüğünde çevrenin de çeşitli savunma avantajlarına sahip olması yanında bu durumun burayı tutmak için gerekli insan sayısının toplanmasını güçleştireceği yani bu sayıyı azaltacağını düşünmekteydi. Kitchener'ın fikrine göre eğer Türk ordusu rahat ve rakipsiz biçimde Alman niyetlerine bırakılırsa Yakın Doğu'daki Fransız ve İngiliz varlıklarının göreceği olumsuz etki çok büyük olacak ve Gelibolu'dan bir geri çekiliş bu kötü etkiyi şiddetlendirecekti. Öyle ki, bu sayede Araplar Almanların eline terk edilmiş olacak ve Müttefiklere karşı bir birlik oluşturulabileceklerdi. Bunun daha da geniş etkisi Mısır'ın batı sınırı boyunca ortaya çıkacak saldırılarla karşı karşıya kalınması hatta Tunus, Cezayir ve Fas'a genişlemesi olacağını düşünüyordu. Kitchener bu bağlamda Mısır ve Sudan'da karışıklıklar ve isyanlar çıkararak ve bu durumun Kanal'ın uzun bir süre kapatılmasına neden olabileceğini belirtiyordu. Kitchener mümkün olduğunca hızlı bir şekilde karar alınması konusunBakış da uyarmaktaydi ${ }^{71}$.

Fransız Genelkurmayı tarafından hazırlanarak Londra'daki Fransız askeri ataşesi Albay de la Panouse ve Kaptan Doumayrou tarafından İngiliz Savaş Bakanlığı'na 16 Kasım 1915'te verilen yazıda Kitchener'in önerisi konusunda Fransız Genel Kurmayı'nın fikirleri şu şekilde sıralanıyordu.

1- Böylesine büyük bir seferin hazırlıkları biraz zaman gerektirir ve bu zaman içerisinde Türkler cephane ve materyal ikmallerini yapabilirler.

70 TNA, WO 106/1570, 11 Ocak 1915, “Expedition to Alexandretta- Naval Considerations Regarding a Proposal to Land Troops at Ayas Bay, Gulf of Iskenderun", s. 2-3.

71 TNA, WO 106/1570, 11 Ocak 1915, s.3. 
2- Hazırlıklar için gerekli en kısa zaman içerisinde dahi böylesi bir seferin mutlak gizlilik ilkesi sekteye uğrayacaktır.

3- Ateş altında yeni bir çıkarmanın riskleri çok büyüktür.

4- Kitchener'ın önerisi tüm sonuçları ile yeni bir operasyon yaratması ile sonuçlanır.

5- Sonuç olarak Akdeniz'deki İngiliz nakliyesinin yavaşlık oranı zorluklar ve belki imkânsızlıklar gösterir. Bu duruma ilave ihtiyaçların karşılanması da eklendiğinde çok daha büyük zorluklara dönüşebilir.

Fransız Deniz Kuvvetleri'nin temsilcileri Amiralliğin görüşlerine tamamen katılmaktadır ve şu noktaları vurgulamaktadırlar:

1- Akdeniz'deki düşman denizaltılarının etkisiz hale getirilmesi gerekliliği birinci önem olarak düşünülmelidir ve birliklerin nakli buna bağlı olmalıdır.

2- Denizaltılar Ayas Körfezi'nde ağlar tarafından engellenebilir, ama burada demirli gemiler deniz altıların ağların dışından yapacakları torpido atışına karşı güvende olmayacaktır.

3- Fransız ticaret filosu birliklerin önemli hareketlerinde gerekli olan nakliyelerini saptayacak pozisyonda değildir, eğer böyle bir harekete karar verilirse gerekli gemiler İngiliz donanması tarafından karşılanmak zorunda olacaktır².

Diğer yandan Fransızlar İngiliz Deniz Kuvvetlerinin burada Fransa'ya rağmen bir operasyona girişmesi ihtimalinden çekiniyor olmalı ki, Paris'teki İngiliz Elçisi Bertie'ye gönderilen bir yazıda Fransız Genelkurmayına ne Anadolu'nun doğu kısmında ne de Suriye'de bir askeri operasyona girişilmeyeceği, eğer burada bir operasyon yapılması düşünülürse bunun Fransız askeri yetkililerle görüşülmeden yapılmayacağının bildirilmesi isteniyordu. Son olarak İngiliz Dışişleri Bakanı Fransa'daki İngiliz elçisi Bertie'ye şöyle diyordu: "Fransa'nın Suriye hakkında hissiyatının tamamen farkındayım ve bizim bunu önemsememek gibi bir niyetimiz yok"73. Gerçekten de ne Fransa'nın hassasiyetinin tam olarak üzerine gidilmiş ve İngiltere tek başına bir operasyona girişmişti ne de İskenderun'a bir operasyon fikrinden tam anlamıyla vazgeçilmişti. Operasyonun gerekliliği üzerinde duran Kitchener'ın bu tutumda etkisi olduğu açıktır. Yazışmaların yapıldığı günlerde Halep Vilayeti'nden İskenderun ile Payas arasının bombardıman edilip edilmediğinin sık sık sorulmasından öyle anlaşılıyor ki böyle bir beklenti 1915 sonunda halâ mevcuttu ${ }^{74}$. Diğer yandan bölgenin güvenliğinden sorumlu olan Cemal Paşa'nın İskenderun Limanı'nın torpillenmesi için tedbir almaya

72 TNA, WO 106/1570, 16 Kasım 1915, "Expedition to Alexandretta-Opinion of the French General Staff on the Subject of Earl Kitchener's Proposals", s. 3-4.

73 TNA, FO, 371/2480, 170980/2602, 235, 13 Kasım 1915, Dışişleri Bakanlığından Lord Bertie'ye; Paris elçisi kendisine verilen direktifi yerine getirdiğini ve bu teskin edici sözleri sözlü olarak bildirdiğini haber veriyordu; TNA, FO, 371/2480, 172627/878, 250, 17 Kasım 1915, Bertie'den Dışişleri Bakanlığg'na.

74 BOA, DH.EUM.6.Şb.,2/28, 7 Kanun-1 evvel 1331 (20 Aralık 1915).

Akademik Bakış 43 Cilt 7 Sayı 14 Yaz 2014 
devam ettiği anlaşılmaktadır. 1916 yılı başında Cemal Paşa'nın Başkumandanlık ile yaptığı bir yazışmada İskenderun Limanı için evvelden istediği torpillerin son olarak istediği 500 mayından hariç olduğunu bildiriyordu ${ }^{75}$. Elbette bunda İngiltere'nin tüm limanları olduğu gibi İskenderun'u da sık sık tehdit etmesinin etkisi vardı. Ancak Osmanlı kurmaylarının bölgeye yapılması muhtemel bir esaslı operasyon tehdidinin devam ettiğini düşündükleri de açıktır.

\section{Sonuç ve Değerlendirme}

Hızlı bir biçimde Çanakkale Boğazı'nın geçilmesi için İngiltere ve Fransa ortak donanması tarafından yürütülen Çanakkale harekatı en önemli deniz operasyonlarındandı. Deniz Kuvvetleri Bakanı Churchill'in Çanakkale operasyonunun kısa sürede Osmanlı Devleti'ni savaş dışı bırakacağına duyduğu kuvvetli inanç gibi dönemin Savaş Bakanı Kitchener da aynı anda İskenderun üzerine yine Fransız donanmasıyla birlikte bir operasyon başlatılmasının önemine inanıyordu.

Burada alınacak bir başarının İtilaf güçlerine sağlayacağı faydalar sadece savaş içerisinde stratejik bir noktanın ele geçirilerek Osmanlı ileri kuvvetleri ile gerideki kuvvetler arasındaki iletişimin koparılması gibi bir getiri sağlamayacaktı. Kitchener'ın bir memorandumla uzun uzun anlattığı ayrıntılardan öyle anlaşılıyor ki bu aynı zamanda savaş sonrası Ortadoğu paylaşımında Fransa ve Rusya ile yaşanacak muhtemel sorunların göz önüne alarak teşvik edilmesi zorunlu bir operasyondu. Bu operasyonların gerçekleştirilmesini bu denli isteyen Kitchener'ın isteğinin temelinde Savaş Bakanlığı'ndan evvel Sudan ve Mısır Yüksek Komiserliği yaptığı yıllardan ve hatta ondan evvel Sudan'da görev yaptığı dönemden bölgenin stratejik önemine vakıf olması bulunuyordu. Ancak Fransızların kendilerinin nüfuz alanı olarak gördükleri İskenderun'a İngilizlerle ortak bir operasyona yanaşmak istememelerinde Çanakkale Boğazı'ndaki muharebenin Fransızlar için de ezici bir yük getirmesi kadar İngiltere ile yaşanacak operasyon sonrası aidiyet sorunları da etkiliydi. Zaten aynı anda iki çıkartma yapılmasına Fransız Deniz Kuvvetleri Komutanlığı razı olmamıştı. Bu ve buna benzer anlaşmazlıklar zaman zaman iki müttefik arasında söz konusu olagelen meselelerdendi. Kitchener'ın 1916 yılı Mayısında Rusya'nın Archangel sahillerine ulaşmak üzere yola çıktığı Hampsire isimli savaş gemisinin batırılması sonucu hayatını kaybetmesi ${ }^{76}$ ile İskenderun Limanına çıkarma yapılması konusunda ısrar eden bir İngiliz yetkili de kalmamıştı. Zira Çanakkale Boğazı'ndaki harbin neticesinin de İngiltere'nin istediği şekilde olmaması ve başta Deniz Kuvvetleri Bakanı Churchill olmak üzere bu işe inanan pek çok devlet adamının öngörülerine duyulan inancı zedelemişti. Muhtemeldir ki, bu mağlubiyet deniz çıkarmalarının oldukça zorlu ve riskli olduğunu göstermiş ve İskenderun sahillerine bir çıkarma harekatı için ciddi düşünülmesini gerektir-

75 ATASE, K: 172, D: 744, F: 48, B:1, 10 Mart 1332 (23 Mart 1916).

76 Ballard, a.g.e., s.307. 
mişti. Bundan sonra Çanakkale harekâtı gibi kapsamlı ve Fransızlarla işbirliği içerisinde gerçekleştirilecek bir operasyona girişilmemiş ancak mümkün olan en sert biçimde sahillerin abluka altında tutulması için çaba gösterilmiştir.

Savaş sırasında bir operasyonla çıkarma yapılması fikrini uzun süre tartışan Müttefiklerin İskenderun'a girişi ise savaş sonunda imzalanan Mondros Ateşkes Antlaşması hükümleri gereği mümkün olabilmiştir. 3 Kasım 1918'de İskenderun ağzındaki liman açılarına gelen bir Fransız mayın tarama gemisi liman ağzındaki mayınları temizlemiş ardından da Fransızlar İskenderun Limanı'ndan faydalanmak için Osmanlı Devleti'nden izin istemiştir. Ancak henüz bu izin gelmeden 9 Kasım 1918'de İngilizler, 10 Kasım'da da Fransızlar İskenderun'a çıkmıştır. ${ }^{77}$ İsgale direnen İskenderun kaymakamı Payas'a sürülmüş, 14 Kasım'da asıl Fransız birlikleri şehre yerleşmiştir. Kaymakam ve liman başkanı tutuklanmış, 2. Ordu Komutanı Nihat Paşa'nın protestosu işe yaramamış ve 15 Kasım'da Fransız kuvvetleri Belen ile bölgedeki işgallerine devam etmişlerdir. Ardından 28 Kasım'da bir İngiliz birliği Payas'a çıkmış. 2 Aralık 1918'de Dörtyol'u Fransızlar işgal etmiştir. Ancak bu bölgede Milli kuvvetlerinin sert direnişi ile karşılaşmıştır. 19 Aralık 1918'te Dörtyol-Özerli'de Fransız birliğine baskın yapılmış, Karakese'de Fransız destekli Ermeni kuvvetleri dağıtılmıştır. Bu çatışmalar Kurtuluş savaşındaki ilk silahlı çatışmalar olarak kayda geçmiştir ${ }^{78}$.

Aslında İskenderun'un Müttefiklerin işgaline uğraması, savaşın başlarında Kitchener'ın yazdığı bir memorandumda üzerinde durduğu gelişmenin vücut bulmasıydı. Savaş sonrasında Fransa ile nüfuz mücadelesine girileceğini düşünen Kitchener buraya sahip olmanın önemini biliyordu. Ancak daha büyük paylar karşısında bu feraagata değer görülen İskenderun'un Fransızlara sözde özerk bir yönetim tarzıyla terki Anadolu'nun bağımsızlığı için çarpışılan yıllarda dahi Mustafa Kemal'in kabullenebildiği bir durum değildi. Öyle ki, bölgedeki yerel direniş Fransızlar ve beraberinde Ermeni lejyonuna karşı başarılı olmuş ve genel itibariyle Güneydoğu Anadolu'daki Fransız işgal bölgesinde bir antlaşma ile buradan çekilme isteği artmıştır. Nihayet 20 Ekim 1921 tarihinde imzalanan Ankara İtilâfnâmesi sonucunda Fransızlar; Adana, Mersin, Osmaniye, Kilis ve Gaziantep'i boşaltmayı kabul ettikleri halde İskenderun'da İskenderun sancağı adıyla ve Suriye sınırları içinde özel bir idarî muhtariyet verilmesini kabul ettiler. Lozan Konferansı sırasında Türk heyeti İskenderun'un statüsünü özellikle bir görüşme konusu yapmamaya ve Ankara Antlaşması'na sadık kalmaya özen gösterdiler ${ }^{79}$.

77 Kemal Çelik, Çukurova'nın işgali döneminde, Fransız propaganda ve casusluk faaliyetleri ile milli kuvvetlerin buna karşı yayımladığı 1920 tarihli yeni bir belge, Gazi Akademik Bakış Dergisi C. 2, S. 3, s. 104.

78 Refik Kireçci, İskenderun, byy,. 1996, s.18.

79 Mustafa Budak, "TBMM Gizli Celse Zabıtlarına Göre Lozan Konferansı ve İskenderun Sancağı”,

Akademik Bakış 45 Cilt 7 Sayı 14 Yaz 2014 
Ancak Misak-1 Milli sınırları içerisinde olan İskenderun'un vaziyeti için doğru zaman bekleniyordu. Mustafa Kemal 1936 yılı TBMM'nin Beşinci dönem ikinci toplanma yılını açılış konuşmasında meselenin çözümü için duyduğu isteği şu sözlerle belirtiyordu: "Bu sırada, milletimizi gece-gündüz meşgul eden başlıca büyük bir mesele, hakiki öz Türk olan 'skenderun-Antakya ve havalisinin mukadderatıdır. Bunun üzerinde, ciddiyet ve katiyetle durmaya mecburuz." ${ }^{\circ 0}$. Mustafa Kemal Paşa, stratejik açıdan da önemini bildiği İskenderun'un Türkiye sınırlarına katılması için dünya konjonktürünün de getireceği şartları değerlendireceğinin işaretini veriyordu: "Daima kendisi ile dostluğa çok ehemmiyet verdiğimiz Fransa ile aramizda tek ve büyük mesele budur. Bu işin hakikatini bilenler ve hakki sevenler, alakamızın şiddetini ve samimiyetini iyi anlarlar ve tabii görürler. Önümüzdeki sene, müzakereler ve silahlanma yarışları ile büyük bir hazırlık senesi olacağa benziyor. Devletlerarasındaki intilafların anlaşmalara varmasinı samimiyetle dileriz"si.

Yaklaşan II. Dünya Savaşı'nın Avrupa'da hissedilmeye başlandı̆̆ı böylesine bir ortamda sorunun halledilmesi için uygun ortam olacağını bilen Mustafa Kemal Paşa'nın mücadelesi bu konuşmasından yaklaşık iki yıl sonra çözümle neticelenmiştir. Öyle ki, İskenderun üzerinde kademeli olarak arttırılan hak mücadelesi neticesi Temmuz 1938'de burası Türkiye'ye bağlanmıştır. Bu şekilde İskenderun (yeni adıyla Hatay) sorununun çözülmesi Mustafa Kemal Atatürk'ün vefatından evvel çözüme kavuşturulan son mesele olmuştur.

\section{Kaynaklar}

\section{Arşivler}

1- Başbakanlık Osmanlı Arşivi, İstanbul /Türkiye

DH.EUM. 6.Şb., 2/67, DH.EUM.4.Şb., 1/19, DH.EUM.6.Şb.,2/28, DH.ŞFR, 457/73, DH.ŞFR., 456/108, DH.ŞFR., 456/1 16, DH.ŞFR., 459/78, DH.ŞFR., 460/15.

2- Cambridge University Library Archives,

Hardinge Papers, 121, No: 16.

3- Churchill Archives, Churchill College, Cambridge/ Ingiltere

Akademik CHAR, 2/74, CHAR, 13/35 CHAR, 13/37, CHAR, 13/35, CHAR, 2/74-51, CHAR, 13/67, CHAR, 2/74, CHAR, 13/67.

4- Genelkurmay Başkanlığı, Askeri Tarih ve Stratejik Etüt Dairesi Başkanlığı Arşivi, Ankara/Türkiye

K: 172, D: 744, F: 48/1, K: 448, D: 1767, F: 47.

5- The National Archives, Kew, Londra/ İngiltere

FO, 371/2138, FO 371/2485, FO, 371/2138, FO, 371/2143, FO, 371/2145, FO, 371/2146, FO, 371/2478, FO 371/2480, WO 106/1570, CAB, 24/1, CAB, 24/2.

İlmî Araştırmalar 2, İstanbul 1996, s. 39-46.

80 Atatürk ün Söylev ve Demę̧leri, Atatürk Araştırma Merkezi Yay, C. 1, Ankara 1997, s. 410.

81 A.g.e., s. 410. 


\section{Diğer Kaynaklar}

ARSLAN, Ali, “İngilizlerin İskenderun'u İşgal Projesi ve Osmanlı Devletinin Aldığı Tedbirler (1914-1915)", IV. Hatay Tarih ve Folklor Sempozyumu, Antakya 1997, ss. 1-27. Atatürk'ün Söylev ve Demeçleri, Atatürk Araştırma Merkezi Yay, C.I, Ankara 1997. BALLARD, C.R., Kitchener, Newnes, London, bty.

BOSTAN, İdris, "Osmanlı Topraklarında Petrolün Bulunuşu ve İskenderun'da İlk Petrol İşletme Çalışmaları", Coğrafua Araştırmaları, C. 1, S.2, Ankara 1990, SS.129-135.

BUDAK, Mustafa, "TBMM Gizli Celse Zabıtlarına Göre Lozan Konferansı ve İskenderun Sancağı", İlmî Araştırmalar 2, İstanbul 1996, ss.39-46.

Cemal Paşa, Hatıralar, Haz: Alpay Kabacalı, İş Bankası Yay., İstanbul 2006.

ÇABUK, Vahit, “Birinci Dünya Savaşı Öncesinde İskenderun’un Stratejik Durumu", I. Hatay Tarih ve Folklor Sempozyumu, Antakya 1991.

ÇELIK Kemal, Çukurova'nın işgali döneminde, Fransız propaganda ve casusluk faaliyetleri ile milli kuvvetlerin buna karşı yayımladı̆̆ı 1920 tarihli yeni bir belge, Gazi Akademik Bakış Dergisi C. 2, S. 3, s. 103-124, Ankara 2008.

ERDEN'Ali Fuad, Birinci Dünya Savaşı'nda Suriye Hatıraları, (Yay. Haz: Alpay Kabacalı), Türkiye İş Bankası Yay., İstanbul 2006.

ERICKSON, Edward J, "Captain Larkin and the Turks: The Strategic Impact of the Operations of HMS Doris in Early 1915", Middle Eastern Studies, Vol. 46, No. 1, Ocak 2010, ss.151-162.

GILBERT, Martin, Winston S. Churchill (1914-1916), Vol:3, Part I, Heinemann, London 1972.

KELEŞYILMAZ, Vahdet, “Belgelerle Türkiye'nin Birinci Dünya Savaşına Giriş Süreci", Erdem, C: 11, S: 31, Mayıs 1999, ss. 139-153.

KİREÇCi, Refik, İskenderun, byy, 1996.

Sofya Askeri Ataşesi, Mustafa Kemal in Raporları (Kasım 1913- Kasım 1914), Yay. Haz: Ahmet Tetik, Genelkurmay Askeri Tarih ve Stratejik Etüt Dairesi Başkanlığı Yay., Ankara 2007.

The Arab Bulletin, Bulletin of the Arab Bureau in Cairo, 1916-1919, Vol. I, London 1986. TÜRKMEN, A.Faik, Mufassal Hatay, 3. Cilt, Reklam Basımevi, İstanbul 1937.

Akademik Bakış 47 Cilt 7 Sayı 14 Yaz 2014 
- 